Article

\title{
Short-Range Stacking Disorder in Mixed-Layer Compounds: A HAADF STEM Study of Bastnäsite-Parisite Intergrowths
}

\author{
Cristiana L. Ciobanu ${ }^{1, *}$, Alkis Kontonikas-Charos ${ }^{1}$, Ashley Slattery ${ }^{2}$, Nigel J. Cook ${ }^{1}$ (D), \\ Kathy Ehrig ${ }^{3}$ (D) and Benjamin P. Wade ${ }^{2}$ \\ 1 School of Chemical Engineering, The University of Adelaide, Adelaide, SA 5005, Australia; \\ alkiviadis.kontonikas-charos@adelaide.edu.au (A.K.-C.); nigel.cook@adelaide.edu.au (N.J.C.) \\ 2 Adelaide Microscopy, The University of Adelaide, Adelaide, SA 5005, Australia; \\ ashley.slattery@adelaide.edu.au (A.S.); benjamin.wade@adelaide.edu.au (B.P.W.) \\ 3 BHP Olympic Dam, Adelaide, SA 5000, Australia; kathy.ehrig@bhpbilliton.com \\ * Correspondence: cristiana.ciobanu@adelaide.edu.au; Tel.: +61-405-826-057
}

Received: 3 October 2017; Accepted: 13 November 2017; Published: 20 November 2017

\begin{abstract}
Atomic-scale high angle annular dark field scanning transmission electron microscopy (HAADF STEM) imaging and electron diffractions are used to address the complexity of lattice-scale intergrowths of REE-fluorocarbonates from an occurrence adjacent to the Olympic Dam deposit, South Australia. The aims are to define the species present within the intergrowths and also assess the value of the HAADF STEM technique in resolving stacking sequences within mixed-layer compounds. Results provide insights into the definition of species and crystal-structural modularity. Lattice-scale intergrowths account for the compositional range between bastnäsite and parasite, as measured by electron probe microanalysis (at the $\mu \mathrm{m}$-scale throughout the entire area of the intergrowths). These comprise rhythmic intervals of parisite and bastnäsite, or stacking sequences with gradational changes in the slab stacking between B, BBS and BS types (B-bastnäsite, $\mathrm{S}$ - synchysite). An additional occurrence of an unnamed $\mathrm{B}_{2} \mathrm{~S}$ phase $\left[\mathrm{CaCe}_{3}\left(\mathrm{CO}_{3}\right)_{4} \mathrm{~F}_{3}\right]$, up to 11 unit cells in width, is identified among sequences of parisite and bastnäsite within the studied lamellar intergrowths. Both $\mathrm{B}_{2} \mathrm{~S}$ and associated parisite show hexagonal lattices, interpreted as $2 H$ polytypes with $c=28$ and $38 \AA$, respectively. $2 H$ parisite is a new, short hexagonal polytype that can be added to the 14 previously reported polytypes (both hexagonal and rhombohedral) for this mineral. The correlation between satellite reflections and the number of layers along the stacking direction $\left(c^{*}\right)$ can be written empirically as: $\mathrm{N}_{\mathrm{sat}}=[(\mathrm{m} \times 2)+(\mathrm{n} \times 4)]-1$ for all $\mathrm{B}_{\mathrm{m}} \mathrm{S}_{\mathrm{n}}$ compounds with $\mathrm{S} \neq 0$. The present study shows intergrowths characterised by short-range stacking disorder and coherent changes in stacking along perpendicular directions. Knowing that the same compositional range can be expressed as long-period stacking compounds in the group, the present intergrowths are interpreted as being related to disequilibrium crystallisation followed by replacement. HAADF STEM imaging is found to be efficient for depiction of stacking sequences and their changes in mixed-layer compounds, particularly those in which heavy atoms, such as rare-earth elements, are essential components.
\end{abstract}

Keywords: HAADF STEM; REE-fluorocarbonates; short-range stacking disorder; mixed-layer compounds

\section{Introduction}

Advanced electron microscopy of foils prepared by focused ion beam-scanning electron microscopy (FIB-SEM) allows atomic-scale insight into patterns of element distribution in minerals, with significance for both petrogenesis and the minerals industry [1]. High angle annular dark 
field-scanning transmission electron microscopy (HAADF STEM) is a particularly useful technique for showing nanoscale features of materials, including nanoparticles, smallest atomic clusters, or the crystal-structural motifs in sulphosalt minerals with complex chemistry (e.g., [1-3]).

Among minerals of emerging economic significance are the REE-fluorocarbonates which comprise the majority of worldwide REE reserves (e.g., [4]). These minerals are reported from a variety of magmatic environments, ranging from basaltic vacuoles to pegmatites of either granitic or alkaline affiliation (e.g., [5-7]). REE-fluorocarbonates also appear concentrated within a range of deposits that are loosely affiliated to the iron-oxide copper gold (IOCG) clan, including the giant REE-deposit at Bayan Obo, Inner Mongolia, China (e.g., [8]) and Phalaborwa, South Africa [9]. REE-fluorocarbonates are also the dominant REE-carriers in the giant Olympic Dam Cu-U-Au-Ag deposit, South Australia [10,11], and in nearby mineralised prospects [12,13]. The stability of REE-fluorocarbonates could also be useful for tracking thermodynamic conditions of ore deposition since volatiles $\left(\mathrm{F}, \mathrm{CO}_{3}\right)$ are important hydrothermal ligands for transport and deposition of REE and other metals [4,14].

The bastnäsite-synchysite group (BSG) comprises REE-fluorocarbonates with mixed-layer structures in which REE- (hereafter, Ln) and Ca-bearing layers with various stacking arrangements can adapt to any intermediate composition between the end-members bastnäsite $\left(\mathrm{LnFCO}_{3} ; \mathrm{B}\right.$ slab) and synchysite $\left(\mathrm{LnFCO}_{3} \cdot \mathrm{CaCO}_{3} ; \mathrm{S}\right.$ slab) [15-17]. Fluorine is contained within the Ln layer whereas $\mathrm{CO}_{3}$ groups form the ligand layers, either between two LnF layers, or between LnF and Ca layers (see below). There are currently only two other named mineral phases within the group: parisite $\left(2 \mathrm{LnFCO}_{3} \cdot \mathrm{CaCO}_{3} ; \mathrm{BS}\right)$ and röntgenite $\left(3 \mathrm{LnFCO}_{3} \cdot 2 \mathrm{CaCO}_{3} ; \mathrm{BS}_{2}\right)$. In addition, a handful of $\mathrm{B}_{\mathrm{n}} \mathrm{S}_{\mathrm{m}}$ polysomes and their polytypes, where $n$ and $m$ represent the number of $B$ and $S$ modules, are defined as long-range stacking compounds from transmission electron microscopy (TEM) studies (e.g., [16,18,19]; Table 1). Among these, the $\mathrm{B}_{2} \mathrm{~S}$ polysome is also confirmed from X-ray single crystal studies [19].

The minerals in the group are illustrative of 'polycrystals' (syntaxic intergrowths of two chemically and structurally related species within the same crystal). They also represent one of the prototypes for mixed-layer stacking structures $[15,16,20]$. Euhedral crystals of parisite-(Ce) showing syntaxial intergrowths between various polysomes and their polytypes in the compositional range between parisite and $\mathrm{B}_{2} \mathrm{~S}$ have been documented from a granite-hosted REE-deposit in Sichuan Province, SW China $[18,19,21,22]$. Epitaxial intergrowths of molybdenite with BSG species from the same Ca-poor side of the group (parisite, bastnäsite and their disordered lattice-scale intergrowths) were also reported in a preliminary TEM study of samples from mineralised granite in the vicinity of the Olympic Dam deposit [12]. In this case, the BSG minerals, intergrown with molybdenite and sericite, form an assemblage interpreted to pseudomorphically replace pre-existing plagioclase within red-stained granite [13]. They are illustrative of the link between early iron-metasomatism and REE-Mo-mineralisation at Olympic Dam since sub- $\mu$ m-scale Fe-oxides are documented within pits along the parisite-dominant lamellae and also within K-feldspar in the same samples [12].

The present study employs atomic-scale HAADF STEM imaging supplementing TEM investigation to address the complexity of lattice-scale intergrowths in the aforementioned parisite-bastnäsite assemblages discussed by Kontonikas-Charos et al. [12]. The aims are firstly to define all species present within the intergrowths relative to the compositional range within the BSG minerals, and secondly, to assess the value of the HAADF STEM technique in resolving stacking sequences within long-period mixed layer compounds. 
Table 1. Chemistry, crystal structures and stacking sequences for all phases known in the bastnäsite-synchysite group.

\begin{tabular}{|c|c|c|c|c|c|c|c|c|c|c|c|c|c|c|c|}
\hline Name & $\begin{array}{l}\text { Formula/Layer Types 1* } \\
\text { (after Ni et al. [17]) }\end{array}$ & $\begin{array}{c}\mathrm{CaCO}_{3} \\
(\%)\end{array}$ & Slabs & $\mathrm{B} / \mathrm{S}$ & $\begin{array}{c}\text { Layer Types 2** } \\
\text { (after Donnay and } \\
\text { Donnay [15]) }\end{array}$ & $\mathbf{N}_{\mathrm{sat}}$ & $\begin{array}{c}\text { Space } \\
\text { Group/Sym } \\
\mathrm{m}^{\#}\end{array}$ & $a(\AA)$ & $b(\AA)$ & $c^{\prime \prime \prime}(\AA)$ & $\begin{aligned} & c(\mathbf{x} \mathbf{n})(\AA) ; \\
\mathbf{n}= & \text { number of } c^{\prime \prime \prime}\end{aligned}$ & $\alpha\left({ }^{\circ}\right)$ & $\beta\left(^{\circ}\right)$ & $\gamma\left(\left(^{\circ}\right)\right.$ & References \\
\hline \multirow{12}{*}{$\begin{array}{l}\text { Bastnäsite } \\
\text { (B slab) }\end{array}$} & $\mathrm{Ce}\left(\mathrm{CO}_{3}\right) \mathrm{F}$ & \multirow{2}{*}{0} & \multirow{2}{*}{ B } & & \multirow{2}{*}{ de } & \multirow{2}{*}{2} & \multirow{2}{*}{$P-62 c$} & \multirow{2}{*}{7.16} & \multirow{2}{*}{7.16} & \multirow{2}{*}{4.89} & \multirow{2}{*}{$9.79(\times 2)$} & \multirow{2}{*}{90} & \multirow{2}{*}{90} & \multirow{2}{*}{120} & \multirow{2}{*}{$\begin{array}{l}{[15,17]} \\
\text { this study }\end{array}$} \\
\hline & 1:1:0 & & & & & & & & & & & & & & \\
\hline & $\mathrm{CaCe}_{3}\left(\mathrm{CO}_{3}\right)_{4} \mathrm{~F}_{3}$ & \multirow{2}{*}{25} & \multirow{2}{*}{$\mathrm{B}_{2} \mathrm{~S}$} & \multirow{2}{*}{2} & \multirow{2}{*}{$2 \times(\mathrm{de}) \cdot \mathrm{dgfg}$} & \multirow[t]{2}{*}{8} & \multirow{2}{*}{$\mathrm{R}, \mathrm{H}$} & \multirow{2}{*}{7.13} & \multirow{2}{*}{7.13} & \multirow{2}{*}{4.71} & \multirow{2}{*}{$38.4(\times 8)$} & \multirow{2}{*}{90} & \multirow{2}{*}{90} & \multirow{2}{*}{120} & \multirow{2}{*}{ [19], this study } \\
\hline & 3:3:1 & & & & & & & & & & & & & & \\
\hline & $\mathrm{Ca}_{4} \mathrm{Ce}_{11}\left(\mathrm{CO}_{3}\right)_{15} \mathrm{~F}_{11}$ & \multirow{2}{*}{26.7} & \multirow{2}{*}{$\mathrm{B}_{7} \mathrm{~S}_{4}$} & 1.75 & $7 \times(\mathrm{de}) \cdot 4 \times(\mathrm{dgfg})$ & 30 & $\mathrm{R}, \mathrm{H}$ & & & & $\sim 71$ & & & & [18] \\
\hline & 11:11:4 & & & & & & & & & & & & & & \\
\hline & $\mathrm{Ca}_{3} \mathrm{Ce}_{8}\left(\mathrm{CO}_{3}\right)_{11} \mathrm{~F}_{8}$ & 273 & $B_{1} S_{6}$ & 167 & $10 \times(\mathrm{de}) \cdot 6 \times(\mathrm{dgfg})$ & 44 & $\mathrm{R}_{\mathrm{H}} \mathrm{H}$ & & & & ح104 & & & & [18] \\
\hline & $8: 8: 3$ & 27.3 & $D_{1006}$ & 1.07 & 10 人 (ue & 44 & $N, 11$ & & & & Hot & & & & {$[10]$} \\
\hline & $\mathrm{Ca}_{2} \mathrm{Ce}_{5}\left(\mathrm{CO}_{3}\right)_{7} \mathrm{~F}_{5}$ & 28.6 & $\mathrm{~B}_{3} \mathrm{~S}_{2}$ & 1.5 & $3 \times(\mathrm{de}) \cdot 2 \times(\mathrm{dgfg})$ & 14 & $\mathrm{R}, \mathrm{H}$ & & & & $\sim 33$ & & & & [16] \\
\hline & $5: 5: 2$ & & & & & & & & & & & & & & \\
\hline & $\mathrm{Ca}_{3} \mathrm{Ce}_{7}\left(\mathrm{CO}_{3}\right)_{10} \mathrm{~F}_{7}$ & 30 & $\mathrm{~B}_{8} \mathrm{~S}_{6}$ & 1.33 & $8 \times(\mathrm{de}) \cdot 6 \times(\mathrm{dgfg})$ & 40 & $\mathrm{R}, \mathrm{H}$ & & & & $\sim 94$ & & & & [18] \\
\hline & 7:7:3 & & & & & & & & & & & & & & \\
\hline Parisite & $\mathrm{CaCe}_{2}\left(\mathrm{CO}_{3}\right)_{3} \mathrm{~F}_{2}$ & 33 & BS & 1 & de.dgfg & 6 & $R 3 ; \mathrm{H}$ & 7.12 & 7.12 & 4.67 & $\begin{array}{c}14(\times 3) ; 28(\times 6) ; \\
84.04(\times 18)\end{array}$ & 90 & 90 & 120 & $\begin{array}{l}{[15,16,21,22],} \\
\text { this study }\end{array}$ \\
\hline & $2: 2: 1$ & & & & & & $C c$ & 12.3 & 7.11 & & 28.25 & 90 & 98.24 & 90 & [23] \\
\hline & $\mathrm{Ca}_{4} \mathrm{Ce}_{7}\left(\mathrm{CO}_{3}\right)_{11} \mathrm{~F}_{7}$ & 36.4 & $\mathrm{~B}_{3} \mathrm{~S}_{4}$ & 0.75 & $3 \times(\mathrm{de}) \cdot 4 \times(\mathrm{dgfg})$ & 22 & & & & & $\sim 104$ & & & & [16] \\
\hline & 7:7:4 & & & & & & & & & & & & & & \\
\hline Röntgenite & $\mathrm{Ca}_{2} \mathrm{Ce}_{3}\left(\mathrm{CO}_{3}\right)_{5} \mathrm{~F}_{3}$ & 40 & $\mathrm{BS}_{2}$ & 0.5 & $\mathrm{de} \cdot 2 \times(\mathrm{dgfg})$ & 10 & R3 & 7.13 & 7.13 & 4.62 & $23.1(\times 5) ; 69.4(\times 15)$ & 90 & 90 & 120 & [15] \\
\hline & 3:3:2 & & & & & & & & & & & & & & \\
\hline & $\mathrm{Ca}_{4} \mathrm{Ce}_{5}\left(\mathrm{CO}_{3}\right)_{9} \mathrm{~F}_{7}$ & 44.4 & $\mathrm{BS}_{4}$ & 0.25 & de $4 \times($ dgfg $)$ & 18 & $\mathrm{R}, \mathrm{H}$ & & & & $\sim 85$ & & & & [16] \\
\hline & 5:5:4 & & & & & & & & & & & & & & \\
\hline Synchysite & $\mathrm{CaCe}\left(\mathrm{CO}_{3}\right)_{2} \mathrm{~F}$ & 50 & $\mathrm{~s}$ & 0 & dgfg & 4 & $\mathrm{O}, \mathrm{M}, \mathrm{H} ?$ & 7.1 & 7.1 & 4.56 & $\begin{array}{c}9.12(\times 2) ; 18.2(\times 4) ; \\
54.7(\times 12)\end{array}$ & & & & {$[15,16]$} \\
\hline & 1:1:1 & & & & & & $\mathrm{C} 2 / \mathrm{c}$ & 12.33 & 7.11 & & 18.74 & 90 & 102.68 & 90 & [24] \\
\hline
\end{tabular}

* Layers 1 (after [17] are: $\mathrm{CeF} ; \mathrm{CO}_{3} ; \mathrm{Ca}\left(\mathrm{CO}_{3}\right)$ of thickness = 2.24 $\AA$ except the latter which is $4.25 \AA$; ** Layers 2 (after [15]): $\mathrm{d}=\mathrm{LnF}$ layer; e: $\mathrm{CO}_{3}$ layer between $2 \mathrm{LnF}$ layers; $\mathrm{f}=\mathrm{Ca}$ layer; $\mathrm{g}=\mathrm{CO}_{3}$ layers between a CeF (or LnF) and Ca layers; ${ }^{\#}=$ both $\mathrm{R}$ and $\mathrm{H}$ polytypes documented from TEM studies [16,21,22]. $c(\times \mathrm{n})$ values for named mineral from [15] and for unnamed species calculated according for 1-period of layers in the stacking sequence (Layers 2). Other polytypes for parisite and $B_{2} S$ reported in the literature are given in Table S4. $N_{\text {sat }}-$ number of satellites according to: $\mathrm{N}_{\mathrm{sat}}=[(\mathrm{m} \times 2)+(\mathrm{n} \times 4)]-1$ for all $\mathrm{B}_{\mathrm{m}} \mathrm{S}_{\mathrm{n}}$ compounds with $\mathrm{S} \neq 0$. H—hexagonal, $\mathrm{O}$ —orthorhombic; $\mathrm{R}$-rhombohedral. 


\section{Background}

Syntaxy and epitaxy are concepts used to describe crystals that show X-ray spectra indicating oriented intergrowths between species that are compositionally either the same (e.g., carborundum [25]), or closely related [15], and references therein). The term 'polycrystal' was suggested since most specimens analysed contain intergrowths of two species, with every pair observed except bastnäsite-synchysite [15]. The individual species share a pronounced pseudo-hexagonal centred lattice which is the basis for defining structures with common sub-motifs in terms of $a^{\prime}=a / 2 \cos 30^{\circ}$ and $c^{\prime \prime \prime}=c / \mathrm{n}$ (n-integer), where there is a linear relationship between $c^{\prime \prime \prime}$ and the chemical composition, i.e., decreasing $a^{\prime}$ and $c^{\prime}$ from bastnäsite to synchysite [15]. Subsequent TEM studies have confirmed these findings and increased the number of species by adding seven unnamed polysomes (Table 1), which are recognisable as long-range stacking periods as well as their rhombohedral and/or hexagonal polytypes $[16,18,19]$.

The crystal structure of minerals in this group was qualitatively described in terms of four types of layer, which are parallel to the hexagonal (000l) plane: (d) LnF ionic layers; (e) layers containing $\mathrm{CO}_{3}$ groups between two LnF layers; (f) layers with Ca ions; and (g) layers containing $\mathrm{CO}_{3}$ groups between a Ca- and a LnF-layer [15]. Such notation allows for representation of different structures in terms of stacking sequences as shown in Figure 1. The arrangement of $\mathrm{CO}_{3}$ groups in the (g) layers can be either perpendicular or diagonal to the layer stack defining hexagonal or rhombohedral lattice points.

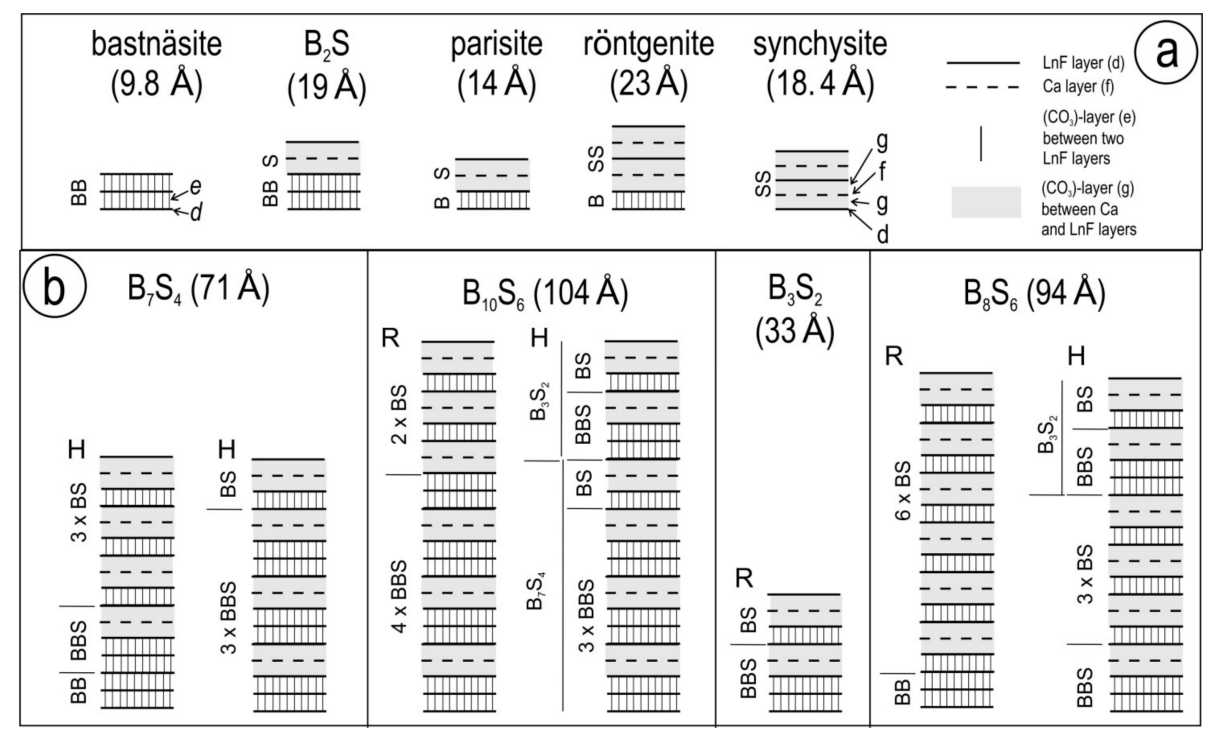

Figure 1. Schematic representation of mixed-layer compounds in the bastnäsite-synchysite group based on the structural model of Donnay and Donnay [15]. Numbers in brackets represents the width of the sequence shown as: one period of the layer sequence except for bastnäsite and synchysite, which are shown as 2 periods (corresponding to $2 \times a^{\prime \prime}$ and $4 \times a^{\prime \prime \prime}$, respectively in (a)); (b) shows polysomes and their polytypes in the range between $\mathrm{B}_{2} \mathrm{~S}$ and parisite $[16,18]$. $\mathrm{H}$-hexagonal; R-rhombohedral.

The extensive syntaxy between the various species was recognised at a very fine scale in the first TEM study that addressed the mixed-layer model for structures of Donnay and Donnay [15], using both direct lattice imaging (in bright and dark field modes) and electron diffractions [16]. The study underpins the systematic variation between the number of satellite reflections on $(000 l)^{*}$ rows (between strong reflections defining the pseudo-period $c^{\prime \prime \prime}$, c.f. [15]), and the number of layers within the two blocks/slabs, B and S. For example, parisite consisting of simple BS slabs shows five weak reflections leading to $\mathrm{d}_{0006}=c / 6$, corresponding to the six layers in the stacking sequence, i.e., two (de) and four (dgfg) layers in the B and S slabs, respectively (Table 1). 
Despite the predictions that syntaxy among BSG phases is the governing rule, pure specimens were also found and used for crystal structure refinement using X-ray diffraction (XRD). These investigations confirm hexagonal symmetry for bastnäsite-(Ce) [17] but not for the two Ca-bearing species examined, synchysite-(Ce) and parisite-(Ce). These are instead interpreted to have monoclinic symmetry [23,24]. Furthermore, these XRD studies led to a different structural model whereby intergrowths of bastnäsite slabs with general formula: $(\mathrm{CeF})_{n}\left(\mathrm{CO}_{3}\right)_{n+1}(\mathrm{n}=\infty$ in bastnäsite, 1 in synchysite, 2 in parisite) are linked by (Ca) layers, the latter introducing a structural offset from hexagonal to monoclinic symmetry [23]. In complex mixed-layer BSG compounds or domains with large unit cells, ' $n$ ' can take different values [26].

The coplanar geometry of the Ca layer in both synchysite and parisite resembles that observed in vaterite, $\mathrm{a} \mathrm{CaCO}_{3}$ polymorph [27]. Ni et al. [23] contend any compounds richer in Ca than synchysite are not possible as this would require $\mathrm{Ca}-\mathrm{Ca}$ links resulting in vaterite-like slabs, unstable under geological conditions. Polytypism in both compounds is presumed by analogy with 2M micas [23,24].

The most recent structural interpretation of the bastnäsite-synchysite group, with the general formula: $\mathrm{Ca}_{\mathrm{m}}(\mathrm{REE})_{\mathrm{n}}\left(\mathrm{CO}_{3}\right)_{\mathrm{n}+\mathrm{m}}(\mathrm{F}, \mathrm{OH})_{\mathrm{n}}$ (bastnäsite, $\mathrm{m}=0, \mathrm{n}=1$; synchysite, $\mathrm{m}=1, \mathrm{n}=1$; parisite, $\mathrm{m}=1$, $\mathrm{n}=2$; röntgenite, $\mathrm{m}=2, \mathrm{n}=3$ [28]), considers order-disorder (OD) formalism akin to that seen in vaterite [29]. In this case, the polytypism and OD phenomena are attributed only to the Ca-based layer (as in vaterite) whereas the REE-layers, although analogous to the Ca-based OD layer, has a p32 layer symmetry and thus their stacking does not lead to polytypism and OD phenomena.

As such, HAADF STEM imaging has not been applied to mixed-layer compounds in general, or to REE-fluorocarbonates specifically despite the potential of the technique for underpinning the layer complexity in long-period stacking sequences.

\section{Experimental}

The thin polished section from which the TEM samples are obtained was initially examined in backscatter electron (BSE) mode using an FEI Quanta 450 Field Emission Gun scanning electron microscope (FEI, Eindhoven, The Netherlands), equipped with a silicon-drift energy-dispersive $\mathrm{X}$-ray spectrometer.

Electron probe microanalytical data on the REE-fluorocarbonate intergrowths was collected using a Cameca SX-Five electron probe microanalyzer (EPMA; Cameca, Paris, France) at Adelaide Microscopy, The University of Adelaide. The reader is referred to Supplementary Material Tables S2 and S3 in Schmandt et al. [11] (www.mdpi.com/2075-163X/7/10/202/s1) for full details of elements analysed, peak/background positions, count times, reference standards, set-up parameters, elemental overlap corrections and minimum limits of detection. The instrument was operated at $15 \mathrm{kV}$ and $20 \mathrm{na}$ and with a spot size of $1 \mu \mathrm{m}$.

Preparation of thinned $(<100 \mathrm{~nm})$ foils from the polished blocks for TEM investigation was performed using a FEI-Helios nanoLab (FEI, Hillsboro, OR, USA) Dual Focused Ion Beam and Scanning Electron Microscope (FIB-SEM) in the same laboratory. Extraction and thinning procedures followed [30]. Each TEM foil was attached to a copper grid.

Initial High-Resolution (HR)-TEM imaging in Bright Field mode (BF) and electron diffraction (illuminated area of $200 \mathrm{~nm}$ ) were performed on a Philips CM200 TEM (Philips, Eindhoven, The Netherlands). The instrument is equipped with a LaB6 source, utilises a double-tilt holder and a Gatan Orius digital camera (Gatan Inc., Pleasanton, CA, USA) and was operated at $200 \mathrm{kV}$. Energy-dispersive X-Ray spectra (EDS) were acquired using an Oxford Instruments X-Max 65T SDD detector (Oxford Instruments, Abingdon, U.K.) running Aztec software. Diffraction measurements were performed using DigitalMicrograph ${ }^{\mathrm{TM}}$ 3.11.1 (Gatan Inc., Pleasanton, CA, USA) and Winwulff $\odot$ 1.4.0 software (JCrystalSoft, Livermore, CA, USA). Data stored in the American Mineralogist Crystal Structure Database (http:/ / rruff.geo.arizona.edu/AMS/amcsd.php) were used for indexing electron diffractions. 
All HAADF STEM imaging and EDS measurements reported here were performed using an ultra-high resolution, probe-corrected, FEI Titan Themis S/TEM (FEI, Hillsboro, OR, USA) operated at $200 \mathrm{kV}$ in the same laboratory. The spot size was 6 and the gun lens was 7 for this analysis. This instrument is equipped with the X-FEG Schottky source and Super-X EDS geometry. The Super- $X$ EDS detector provides geometrically symmetric EDS detection with an effective solid angle of $0.8 \mathrm{sr}$. Probe correction delivered sub-Ångstrom spatial resolution and an inner collection angle greater than 50 mrad was used for HAADF experiments using the Fischione HAADF detector.

\section{Results}

\subsection{Samples and Compositional Range of BSG Phases}

In this study, we use two FIB-prepared TEM foils obtained from BSG intergrowths (Figure 2a-c) which occur as filling of a mm-sized grain of replaced feldspar [13]. The intergrowths are cut across sets of lamellae with varying composition, expressed by different contrast on BSE images. The intergrowths can be divided into those that are: (i) long (up to $100 \mu \mathrm{m}$ in length) and parallel to one another and with molybdenite (Foil 1; also documented in Kontonikas-Charos et al. [12]), and; (ii) shorter $(<50 \mu \mathrm{m})$ sets of the same lamellae types but with variable orientation (Foil 2). In both cases, the brightest species on the BSE images (Ca-poor, bastnäsite) is subordinate to the darker one. The latter is often 'pitted' as it hosts sub- $\mu \mathrm{m}$-sized inclusions of Fe-oxides (Figure 2b; [12]).

The bastnäsite is, in contrast, relatively clean. Some of the shorter and narrower lamellae appear distinct in that they feature rhythmical bands of bright and dark contrast within the same crystal/lamella (Figure 2c). HAADF STEM images of the two foils mimic the BSE images, whereas the BF TEM images show an inversed contrast with such images (e.g., Foil 2 in Figure 3 and Figure S1, respectively). The epitaxial associations between minerals in Foil 1 (BSG species, molybdenite and minor hematite), as well as HR-TEM images of lattice-scale intergrowths between bastnäsite and parisite, were discussed by Kontonikas-Charos et al. [12].

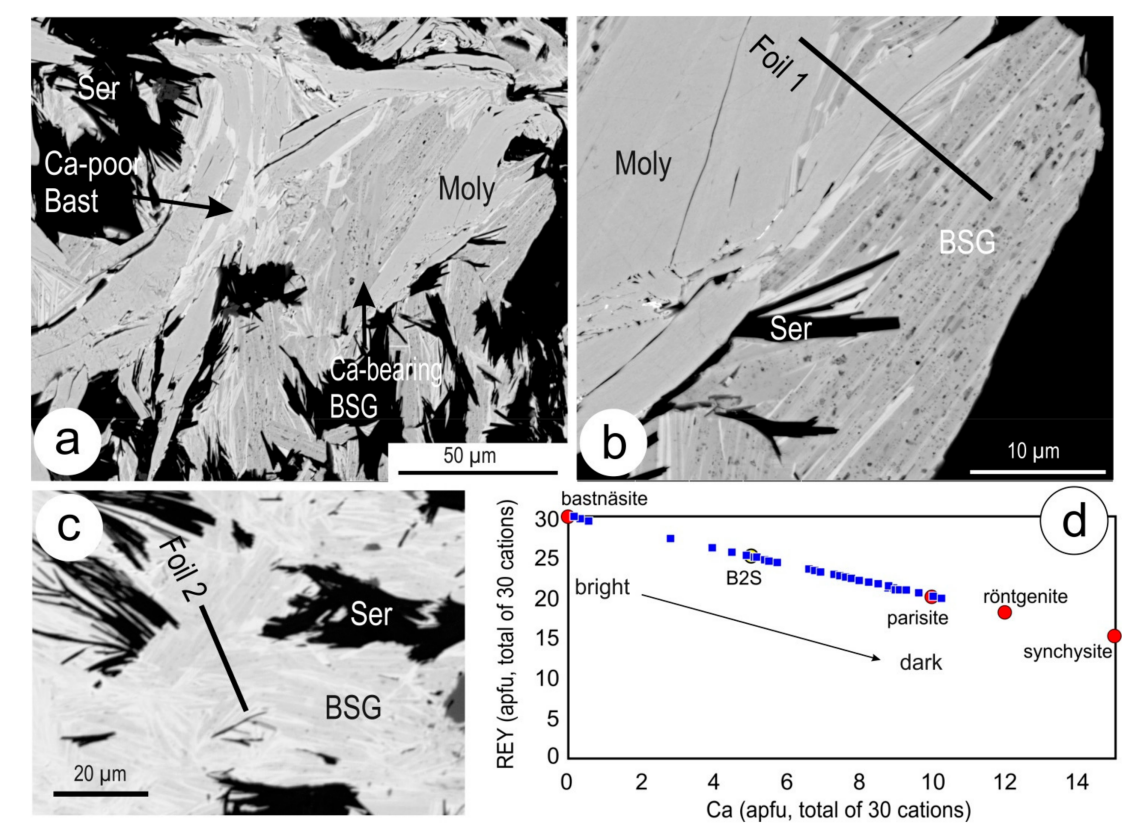

Figure 2. (a-c) Back Scatter Electron (BSE) images showing bastnäsite-synchysite group (BSG) phases as lamellar aggregates intergrown with molybdenite (Moly) and sericite (Ser). Location of focused ion beam (FIB) cuts from where transmission electron microscopy (TEM) foils were obtained is shown in (b,c); (d) Plot REY vs. Ca from electron probe microanalyzer (EPMA) data showing the compositional range of analysed phases shown in $(\mathbf{a}-\mathbf{c})$ within the BSG phases. 
In Foil 2, the lamellar intergrowths between BSG phases are broadly oriented in two directions. At low magnification, most lamellae appear 'composite', either with gradational changes in colour, or contrasting bright and dark domains (Figure 3b). More homogenous parts of lamellae (Figure 3c), or stubby grains with well-defined edges are also identified (Figure 3e). In some cases, such lamella can display a rhythmic banding with bright and dark appearance representing bastnäsite and parisite, respectively (Figure 3f). For comparison with HAADF STEM imaging, Foil 2 and areas of interest are also imaged in BF TEM mode (Figure S1).

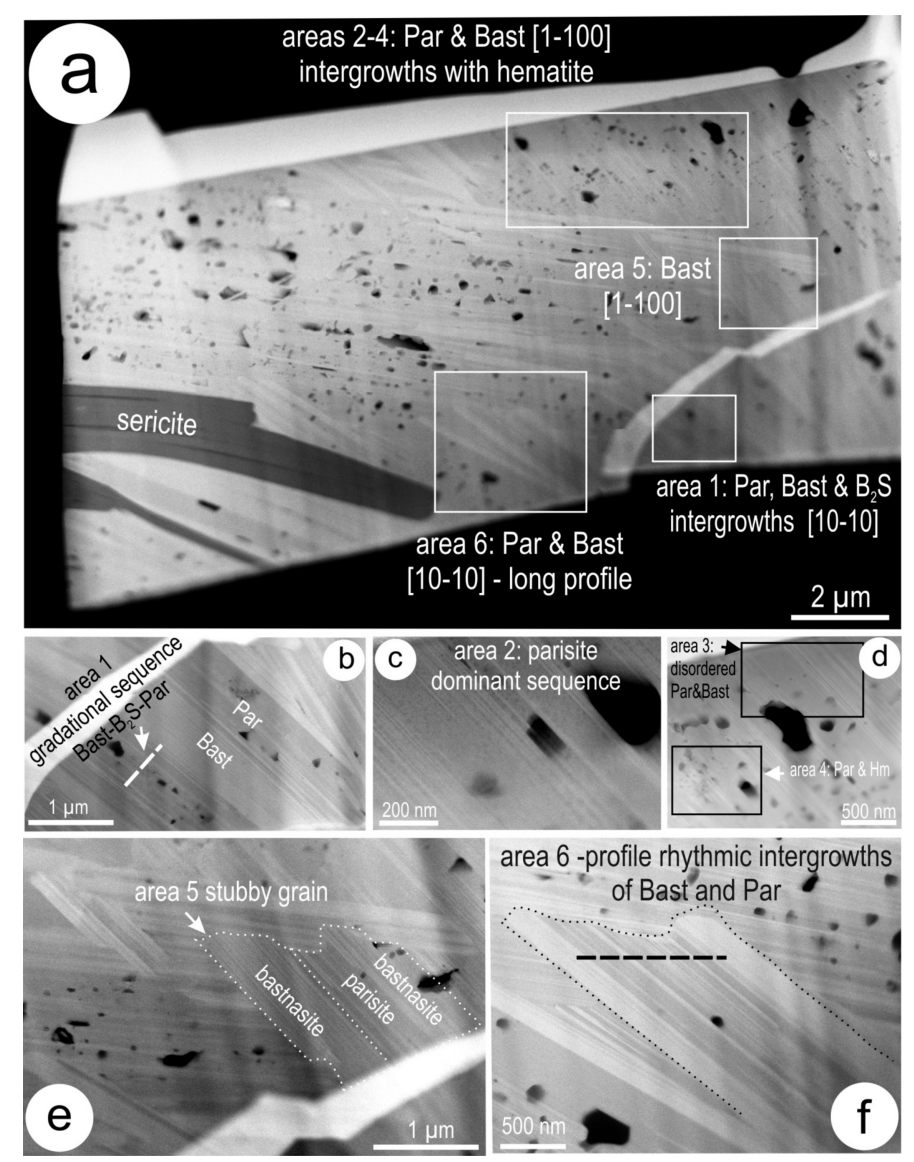

Figure 3. Low-magnification high angle annular dark field-scanning transmission electron microscopy (HAADF STEM) images of Foil 2 in (a) and the areas of interest representing study cases as marked (b-f); The zone axis to which the specimen was tilted for HAADF STEM imaging is marked in (a); Bast—bastnäsite; Hm-hematite; Par-parisite.

Electron probe microanalysis was carried out across the intergrowths around the areas with the FIB-cuts to compositionally constrain the brighter (Ca-poor) and darkest (Ca-richer) phases within the lamellar intergrowths (Figure 2d; Tables S1-S3). Microanalysis confirms predictions based on the stacking sequences and EDX spectra revealed in the preliminary TEM study in terms of the compositional range restricted to the compositional range between bastnäsite and parisite. EPMA data indicate that all species are Ce-dominant. The compositional data (32 individual analyses) plotted as Figure $2 \mathrm{~d}$ defines compositions at the scale of the microprobe beam close to end-member bastnäsite and parisite but also within compositional space between parisite and $\mathrm{B}_{2} \mathrm{~S}$, and to a lesser extent between $\mathrm{B}_{2} \mathrm{~S}$ and bastnäsite. Apart from REY, $\mathrm{Ca}$ and $\mathrm{F}$, elements present at measurable concentrations were $\mathrm{Sr}$ and $\mathrm{K}\left(<0.05 \mathrm{wt} \% \mathrm{SrO}\right.$ and $\mathrm{K}_{2} \mathrm{O}$ ), Th (up to $\left.0.15 \mathrm{wt} \% \mathrm{ThO}_{2}\right)$, Fe $(0.1-0.25 \mathrm{wt} \% \mathrm{FeO}$ ) and $\mathrm{Cl}(<0.1 \mathrm{wt} \%)$. Analyses with Fe concentrations $>0.3 \mathrm{wt} \%$ were not considered as this was readily attributed to mineral inclusions; Fe was not included in the formula calculation. 


\subsection{Stacking Sequences}

Identification of stacking sequences was undertaken using electron diffractions and HAADF STEM imaging on identical areas. These were selected for the range of intergrowths and their heterogeneity as observed from TEM imaging.

\subsubsection{Electron Diffractions and TEM Imaging}

TEM BF imaging of both foils (Figure S2) shows that the lamellar intergrowths among BSG species vary widely in terms of the bright and dark rhythms (tens to hundreds of $\mathrm{nm}$ ), rarely also displaying domains of an intermediate grey colour (identified in Foil 2). Other observed features include the cuspate edges of lamellae that show dark and bright sides, changes in the colour of the sequence along the lamella, as well as smaller, stubby grains or thin, single lamella that crosscut the regular lamellar sequences (Figure S2a-d). The latter are often typical of the darkest species on the BF TEM images, bastnäsite. Image contrast is mostly attributable to variation in chemistry as monitored by TEM EDS spectra giving a range of Ca-bearing BSG phases (brighter phases) and darkest phases with little or no $\mathrm{Ca}$ (bastnäsite). Such data is in agreement with [12]. In some cases, however, the variation in colour is also due to differences in orientation of lamellae from the same bundle.

Electron diffractions were obtained from the BSG phases tilted on the [-1100] and [10 - 10] zone axes, which are pertinent for interpreting stacking sequences from periodicity along the $c^{*}$ axis and their expression in 2-dimensional reciprocal space, respectively (Figures 4 and 5). Although the [11 - 20] zone axis is similar or equivalent to the [10 - 10] zone axis, the latter will be used here for simplicity. Both ordered and disordered patterns were observed over the $\sim 200 \mathrm{~nm}$ diameter of the selected area of electron diffraction (SAED). All SAEDs have orthogonal geometry indicating hexagonal lattices on both zone axes, whereby the smallest $a c^{\prime \prime \prime}$ subcells are marked as strong (Bragg) reflections, and the supercells are marked by satellite reflections with different periodicity along the $c^{*}$ axis (Figures 4 and 5). The ordered supercells show 2-, 6- and 8-fold periodicities on the $c^{*}$ axis and correspond to stacking layers for $c^{\prime \prime \prime}$ in bastnäsite, parisite and the unnamed $\mathrm{B}_{2} \mathrm{~S}$ compound (hereafter called ' $\mathrm{B}_{2} \mathrm{~S}^{\prime}$; Table 1; Figure 4a).

Bastnäsite from wider lamellae shows SAEDs with disorder (streaks between Bragg reflections) but no satellite reflections along $c^{*}$ (Figure $\left.4 \mathrm{~b}\right)$ when tilted on [-1100] zone axis. The $2 \times c^{*}\left(c=2 c^{\prime \prime \prime} \sim 9.8 \AA\right.$ ) periodicity of bastnäsite (Figure $4 \mathrm{c}$ ) is rare and such SAEDs were obtained only from the small, stubby grains (Figure S2e,f) rather than from the coarser lamellae. On the same [-1100] zone axis, parisite is represented by $6 \times c^{*}\left(c^{\prime}=6 c^{\prime \prime \prime} \sim 28 \AA\right)$ patterns with no intensity variation (Figure $\left.4 \mathrm{~d}\right)$. In a few cases, however, the satellite reflections show variable intensity (cf. [16]; Figure 4e). TEM imaging of such parisite-bastnäsite sequences throughout both foils show $\sim 28 \AA$ and $\sim 4.9 \AA$ repeats along the $c$ axis, respectively, with widespread defects as larger units (Figure $\mathrm{S} 2 \mathrm{~g}, \mathrm{~h}$ ) as previously illustrated in Kontonikas-Charos et al. [12].

The 8-fold periodicity on the $c^{*}$ axis $\left(c^{\prime}=8 c^{\prime \prime \prime} \sim 37 \AA\right.$ ) is attributable to $\mathrm{B}_{2} \mathrm{~S}$ (Table 1 ; [19]) and was observed in areas of SAEDs that are otherwise representative of disordered bastnäsite (Figure $4 \mathrm{f}$ ). These were obtained from lamellae that display domains with brightness intermediate between bastnäsite and parisite. The satellite reflections have generally the same intensity. Higher numbers of satellites, with variable intensity, as well as changes between bastnäsite and parisite along the $c^{*}$ axis, were also observed (Figure $4 \mathrm{~g}$,h).

All the SAEDs on [10 - 10] zone axis of the BSG species in the two foils show hexagonal symmetry (Figure 5a) but only the $a 2 c^{\prime \prime \prime}$ bastnäsite is well ordered (Figure $5 \mathrm{~b}$ ). The other SAEDs show a range of satellite reflections, variable in both number and intensity, along $c^{*}$ and parallel directions, suggesting intergrowths between different BSG species. For example, sequences with 6 -fold periodicities along $c^{*}$ and parallel $3 n$ rows displaying the $a c^{\prime}$ superlattice of parisite are intercalated with 2 rows showing 2 -fold ( $a 2 c^{\prime \prime \prime}$ bastnäsite) periodicity, or with rows marked by strong disordering (Figure $5 c, d$ ). The latter are shown as streaks and satellite reflections of variable intensity, nonetheless marking a rectangular pattern indicating a hexagonal lattice. Comparable intergrowths are observed for SAEDs with 8-fold 
periodicities on the $c^{*}$ axis (Figure 5e). Such results require high-resolution imaging to reach a conclusion as to whether the stacking sequences represent (long period) polysomes of various types, or lattice-scale intergrowths between parisite, bastnäsite and $\mathrm{B}_{2} \mathrm{~S}$.

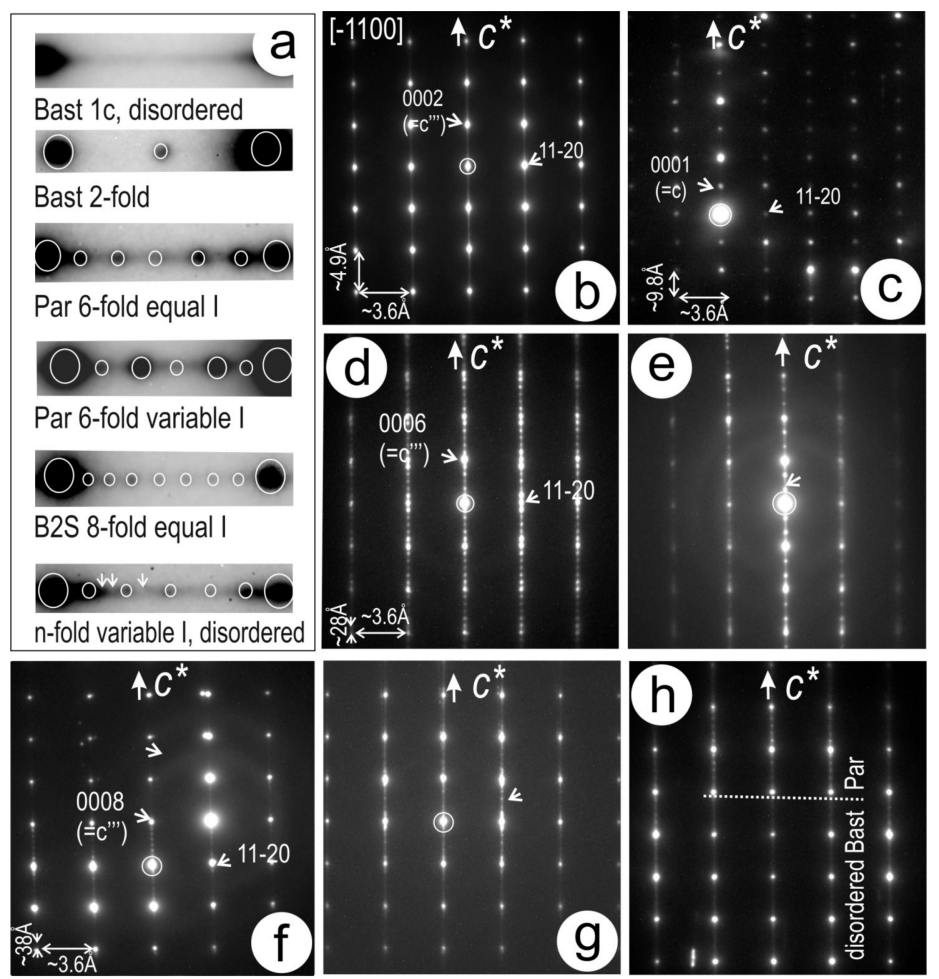

Figure 4. (a) Selection of $000 l^{*}$ rows from selected areas of electron diffraction (SAEDs) in (b-g) showing the distribution of satellites between two Bragg reflections for different mixed-layer compounds as marked. Note that the number of satellite reflections $N_{\text {sat }}$ corresponds to $N-1$, where $N$ is the number of layers within the composing $B(=\mathrm{de})$ and $\mathrm{S}(=\mathrm{dgfg})$ slabs, i.e., $\mathrm{N}_{\mathrm{sat}}=[(\mathrm{m} \times 2)+(\mathrm{n} \times 4)]-1$, for $B_{m} S_{n}$. Changes in the space group symmetry from $P-62 c$ to $P-62 m$ can be inferred based on the presence of $000 l$ reflections with $l \neq 2 n$ as shown in 2-fold bastnäsite (second strip from the top); $(\mathbf{b}, \mathbf{c})$ SAEDs on $[1-100]$ zone axis of the studied BSG species. Disordered (space group $P-62 c$ ) and 2-fold (space group $P-62 m$ ) ordered bastnäsite are shown in (b) and (c), respectively. Parisite with satellite reflections of equal and variable intensity (I) are shown in (d,e); respectively; (f) The $\mathrm{B}_{2} \mathrm{~S}$ phase with equal intensity of satellite reflections ordering along $c^{*}$ within a bastnäsite lattice; (g) Disordered $\mathrm{n}$-fold sequence with variable intensity for satellite reflections along $c^{*}$; (h) Changes in the BSG species along $c^{*}$ indicated by the occurrence of satellite reflections within a disordered bastnäsite lattice. Bast—bastnäsite; Par-parisite.

\subsubsection{HAADF STEM Imaging}

Several areas from Foil 2 were studied in closer detail (Figure 3) after low-magnification imaging both foils in HAADF STEM mode. The image contrast reveals banding within lamellae of various sizes, the smallest being a few hundred nm (Figure $6 a, b)$. These low magnification images also show variation in the rhythms over several orders of magnitude, from just a few $\mathrm{nm}$ in width up to hundreds of nm within the same lamella. The colour variation due to orientation of the lamellae is highlighted by a decrease in contrast (e.g., Figure 6a). Wider parts of lamellar packages can have a homogenous appearance across widths of hundreds of nm (e.g., bastnäsite in Figure 6c). The mutual boundaries between individual lamellae within such aggregates show growth with imbricated relationships (Figure 6a-c), or triple junctions (Figure 6d). In the latter, the scale of banding is below tens of $\mathrm{nm}$. 
The stacking code for compounds in compositional range considered here is illustrated by atomic-scale HAADF STEM imaging of phases that contain both $\operatorname{Ln}(\mathrm{F})$ and Ca layers as, for example, in parisite. When tilted on [1 - 100] zone axis, this reveals bright atoms, attributable to Ln and Ca in order of decreasing intensity ( $\mathrm{d}$ and $\mathrm{f}$ layers, respectively), forming parallel arrays along $h h-2 h 0$ directions with $\sim 3.6 \AA$ distances between them (Figure 7a). These atomic arrays are separated from one another by darker strips at $\sim 4.7 \AA$ along c attributable to the lighter $\mathrm{CO}_{3}$ layers, e and g. Combinations of 'de' and 'dgfg' stacks form the B and S slabs along c with a BS repeat of $\sim 14 \AA$, corresponding to one period of layer stacking in parisite (as shown in Figure 1a). The stacking code in HAADF STEM imaging is in good agreement with the distribution of atoms within the crystal structure of parisite (Figure $7 \mathrm{~b}$ ).
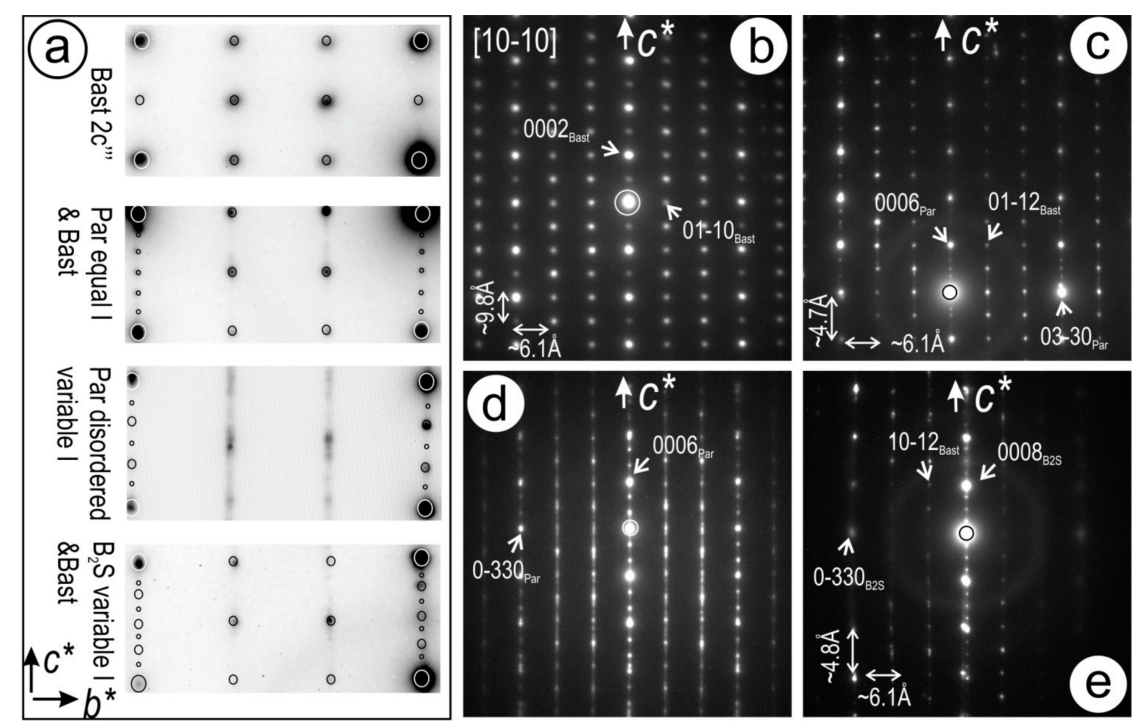

Figure 5. (a) Two-dimensional sections through the reciprocal lattice of studied BSG species and their intergrowths (as marked) showing the distribution of satellite reflections on [10 - 10] zone axis selected from SAEDs in (b-e); Note the orthogonal patterns indicating a hexagonal lattice in all cases; (b-e) SAEDs on [10 - 10] zone axis for bastnäsite (b); intergrowths between parisite and bastnäsite (c); disordered parisite (d); and intergrowths between $\mathrm{B}_{2} \mathrm{~S}$ and bastnäsite (e); Note the ordered 2-fold (or $2 c^{\prime \prime \prime}$ ) bastnäsite obtained by tilting the same grain shown for SAED on [-1100] zone axis in Figure 4c. The SAEDs in (c-e) represent intergrowths imaged on the same zone axis in Figure 10. Bast-bastnäsite; I-intensity; Par-parisite.

Longer sequences of regular B and BS slabs (up to tens of slab repeats in either case), and representing bastnäsite and parisite, respectively (Figure 8a,b), were imaged from many areas in both foils with the specimens tilted to [1 - 100] zone axis. Darkening of B slabs within bastnäsite (Figure 8a) is a common feature and could be interpreted as variation in the proportions of different Ln atoms (more La or $\mathrm{Nd}$ relative to Ce giving lesser or greater average atomic mass, respectively). Single slab defects are always present, as for example, SS slabs within parisite (Figure 8b).

The same stacking code is valid for HAADF STEM imaging of BSG phases on the [10 - 10] zone axis, as shown for parisite and the $\mathrm{B}_{2} \mathrm{~S}$ phase (Figure $8 \mathrm{c}, \mathrm{d}$ ). In this case, however, the shortest distances along $0 k-k 0$ directions are much smaller, $\sim 2.1 \AA$, corresponding to the thickness of individual LnF or Ca layers $\left(=a^{\prime} / 2\right)$. The $B_{2} S$ phase is identified from gradational sequences in area 1 of Foil 2 (Figure $\left.3 a, b\right)$. This consists of BBBS stacks with smallest width at $\sim 38 \AA$ (Figure $8 \mathrm{~d}$ ). Defects are present along both the $\mathrm{c}$ and $\mathrm{b}$ axes, as variable $\mathrm{n} \times \mathrm{B}$ stacks, or changes of layers from $\mathrm{LnF}$ to $\mathrm{Ca}$, respectively. In the latter case, these can be recognised as an array of jogs accounting for a decrease in thickness of the $B$ slabs (Figure 8d). 

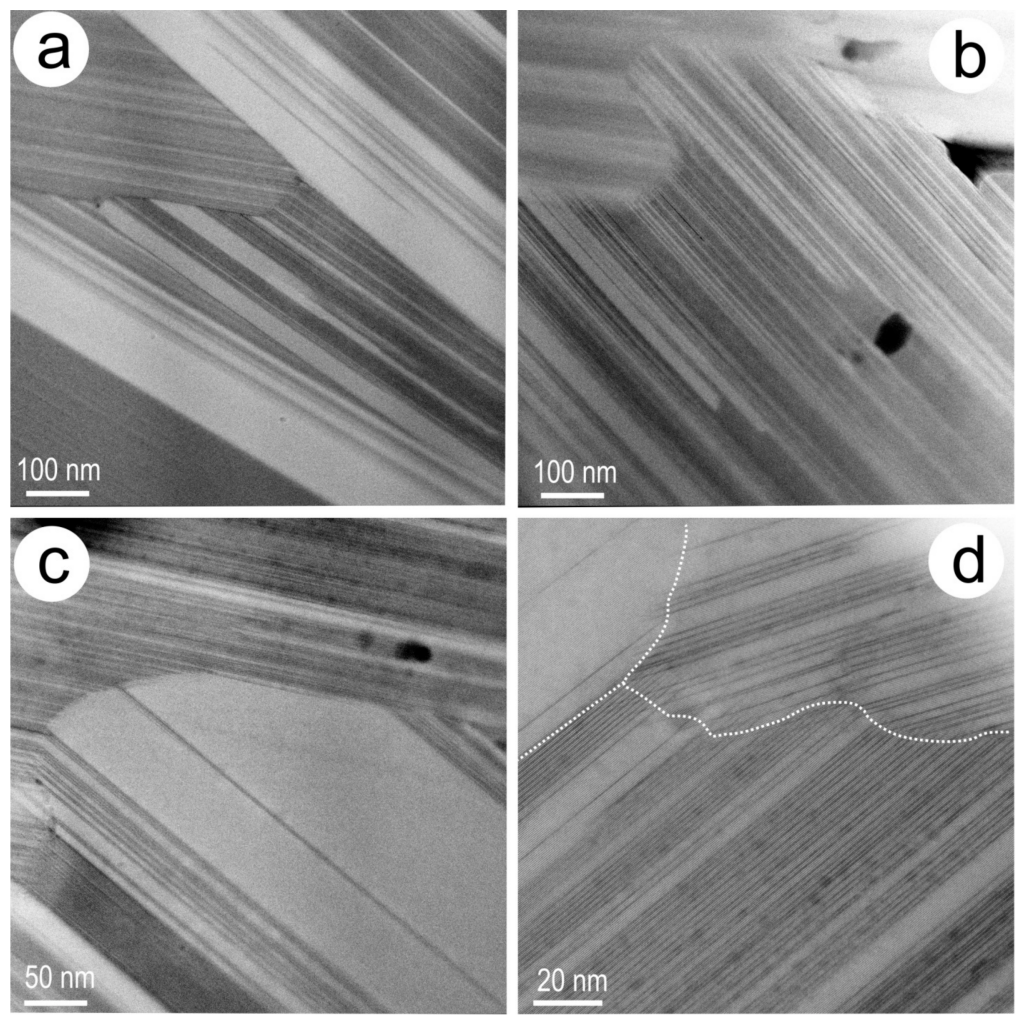

Figure 6. Low-magnification HAADF STEM images of BSG intergrowths showing the wide range of lamellae thickness and their variation in contrast. Note crystal edges indicating such intergrowths include thinner (a few hundred $\mathrm{nm}$ ) lamellae in $(\mathbf{a}, \mathbf{b}) ;(\mathbf{a}, \mathbf{b})$ Rhythmic variation displayed by sharp image contrast within each lamella. The rhythms vary in size from tens to hundreds of nm (a) and from a few to tens of $\mathrm{nm}$ in (b); (c) Edge of lamella showing one side with a wider (hundred $\mathrm{nm}$ ) interval of bastnäsite (bright) and the other as fine-scale rhythms between species with sharp image contrast; (d) Triple junction (dotted line) between lamellae with fine-scale (less than a few to tens of $\mathrm{nm}$ ) intergrowths with rhythmic or gradational changes in contrast. The bright phase at top left is bastnäsite.
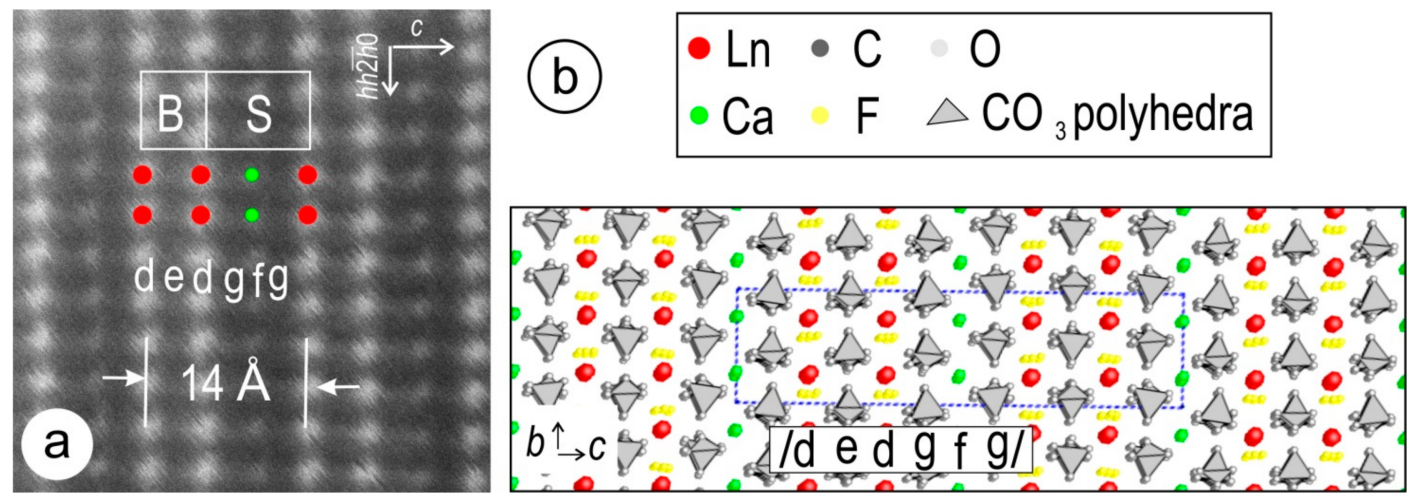

Figure 7. Interpretation of the 'stacking code' for BSG compounds with both Ln and Ca layers as imaged in HAADF STEM mode. (a) Atomic-scale image of parisite viewed down to [-1100] zone axis with superimposed atoms and layers as marked; (b) Crystal structure of parisite (after Ni et al. [23]) showing the correspondence to the stacking layers. Unit cell marked in blue. The orientation (viewed down to $a$ axis) is chosen so that the arrays of atoms correspond to the orthogonal lattice shown in (a). 

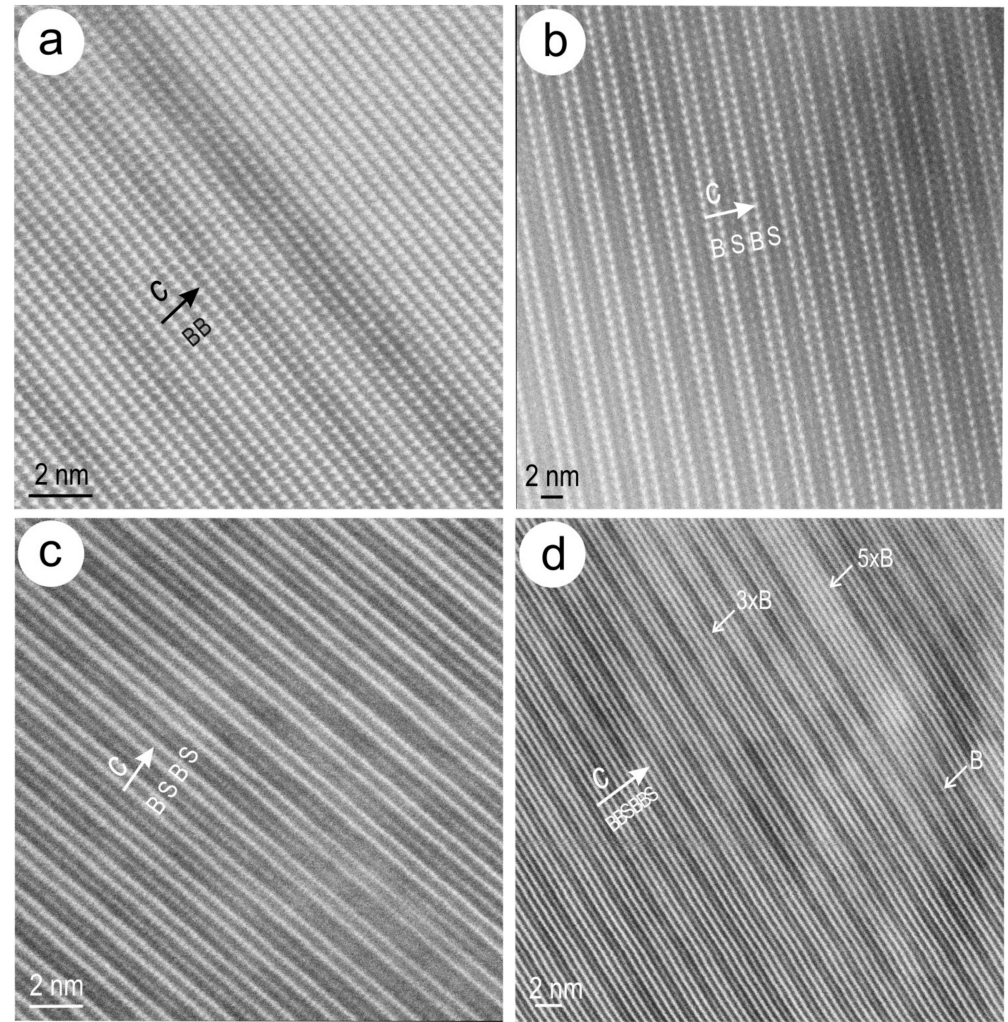

Figure 8. HHADF STEM images showing the typical stacking sequences in the three BSG compounds identified. (a) Bastnäsite down to [-1100] showing the arrays of bright atoms interpreted as Ln (' $\mathrm{d}$ ' layers). The B slab is represented by two rows of bright atoms. Darkening of layers represents most likely an artefact of the foil thickness/uneven orientation; (b,c) Parisite down to [-1100] and [10 - 10] zone axis, respectively. The sequence is characterised by two rows of bright atoms (B slab) and one row of slightly darker atoms (' $\mathrm{f}$ ' layer in the middle of the $\mathrm{S}$ slab); (d) $\mathrm{B}_{2} \mathrm{~S}$ imaged down to [10 - 10] zone axis. Note the density of atoms (at $\sim 2 \AA$ distance) along $b$ axis in (c,d); The sequence is represented by three rows of bright atoms (2B slabs) and one row of slightly darker atoms ( $\mathrm{S}$ slab). Defects as B slabs of variable width are arrowed in (d).

Irrespective of such single slab defects, longer stacking sequences in the 20 to $50 \mathrm{~nm}$ range can be recognised as regular bastnäsite, parisite and $\mathrm{B}_{2} \mathrm{~S}$ intervals such as those imaged from area 1 in Foil 2 (Figure 9a-c). Such intervals can alternate with one another or form rhythms with decreasing widths (Figure 9a). The boundaries of longer intervals of parisite are marked by slab defects towards intervals of bastnäsite (Figure $9 \mathrm{~b}$ ). Likewise, the boundaries between $\mathrm{B}_{2} \mathrm{~S}$ and parisite are marked by sequences with a greater abundance of B slabs alternating with BS (parisite) stacks (Figure 9c).

In closer detail, the stacking disorder observed over 20-30 nm intervals in parisite shows strips of 2-3 units of bastnäsite alternating with irregular sequences of B and S slabs (Figure $9 \mathrm{~d}$ ). Comparably, single S-stack defects within 5 or $6 \times$ B slabs, as well as irregular sequences of B and S slabs over intervals of $\sim 10 \mathrm{~nm}$, are observed in bastnäsite (Figure 9e). Such stacking disorder most likely accounts for the SAEDs with streaks along $c^{*}$ (Figure $4 \mathrm{~b}$ ) observed in bastnäsite from lamellar intergrowths with parisite.

Lamellar intergrowths with strong contrast on HAADF STEM images such as those in area 6 (Figure 3f) are illustrative of one of the stacking sequence $(\sim 1 \mu \mathrm{m})$, in which longer rhythms of bastnäsite and parisite, tens to hundred $\mathrm{nm}$ in width, are seen (Figure $6 \mathrm{a}, \mathrm{c}$ and Figure 10). This profile was imaged across the middle part between the two bastnäsite lamellae of 100-200 nm thickness forming the margins of the sequence (Figure $6 \mathrm{a}, \mathrm{c}$ ). The specimen was tilted on the [10 - 10] zone axis and representative SAEDs are shown in Figure $5 c$,d. The imaging shows three main domains of 
$\sim 320 \mathrm{~nm}$ each: (i) on one side, one of the longest parisite intervals (>200 nm); (ii) in the middle part, short-range (tens of $\mathrm{nm}$ ), irregular rhythms of bastnäsite and parisite with one interval including also the $\mathrm{B}_{2} \mathrm{~S}$ (Figure 10); and (iii) at the other side, an interval of bastnäsite and parisite with gradational changes in the dominant component from the former to the latter (Figure 10). Throughout each of these intervals, stacking disorder is expressed either as single B or S slab defects, or as short range stacking irregularities as shown above (Figure 9).
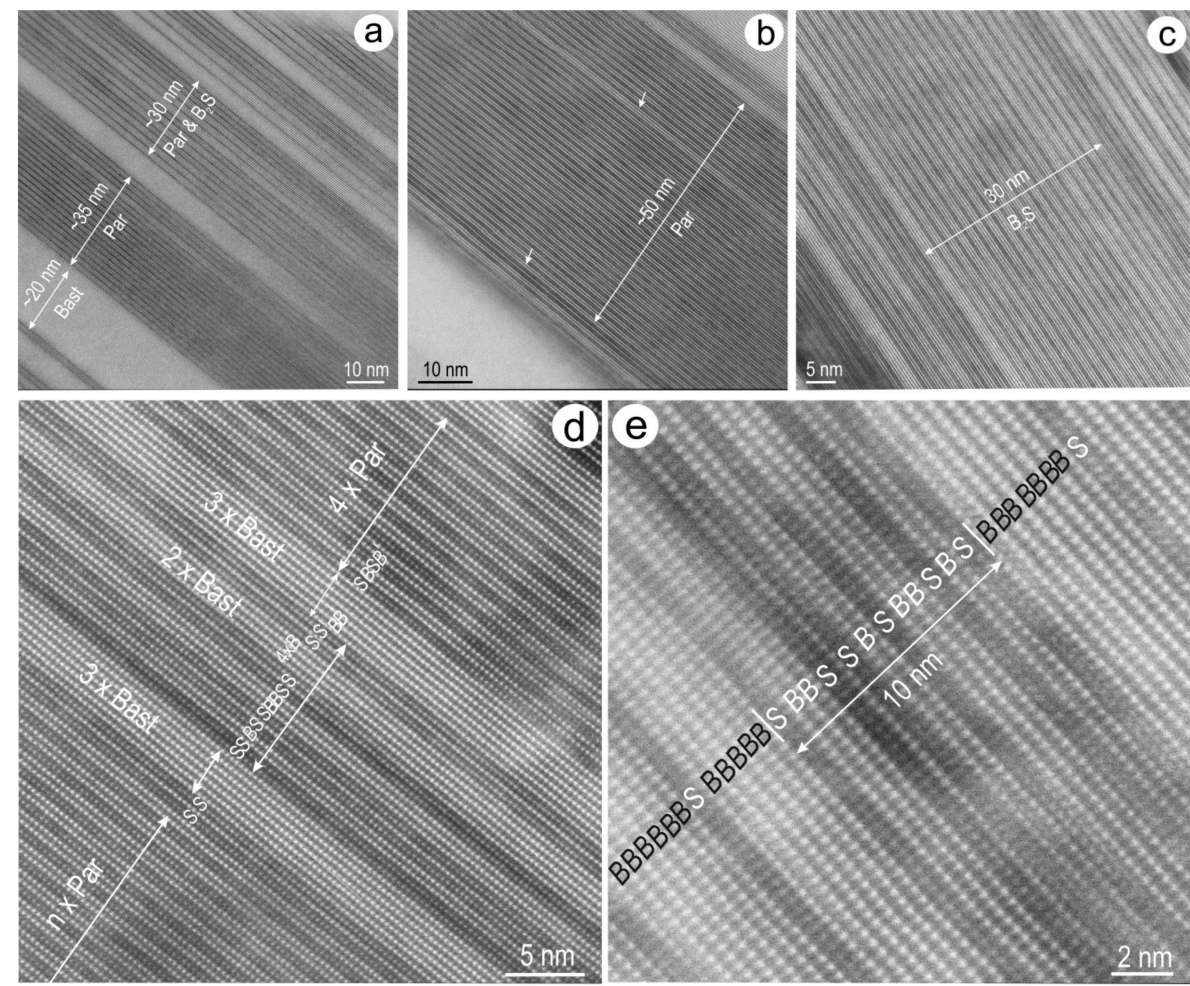

Figure 9. HAADF STEM images showing ordered and disordered stacking sequences over longer (a-c) and shorter (d,e) intervals; (a) Alternating periods of $\sim 20-35 \mathrm{~nm}$ of different phases as marked accounting for transitional contrast changes or compositional variation; $(\mathbf{b}, \mathbf{c})$ Longer $(50-30 \mathrm{~nm})$ periods of parisite and $\mathrm{B}_{2} \mathrm{~S}$ phase, respectively, interspersed with $\mathrm{B}$ stacks of variable widths; $(\mathbf{d}, \mathbf{e})$ Details of stacking sequences in parisite (d) and bastnäsite intervals (e) showing stacking disorder as marked. Note the presence of 1- or 2-periods of BSS slab stacks (corresponding to röntgenite) but with isolated occurrence or erratic distribution throughout the host stacking sequence. Bast—bastnäsite; Par—parisite.

Aside from changes in phase speciation via stacking disorder along the $c$ axis, the BSG species also show changes in slab stacks and composition along other directions (Figure 11). The junctions between BSG phases in lamellae with slight offset to one another show relatively sharp boundaries (Figure 11a). In this case, co-crystallisation is suggested by the stepwise adjustment of B slabs on the longer side of a bastnäsite lamella matching the edges (between sets of S-slabs) of individual lamellae of disordered bastnäsite on the other side of the junction. Such an interpretation is also supported by the absence of open spaces and continuation of single $S$ slabs, albeit with a kink, across the boundary.

Changes between $\mathrm{B}$ and $\mathrm{S}$ slabs on directions perpendicular to the $c$ axis can lead to apparent transformation of bastnäsite into $\mathrm{B}_{2} \mathrm{~S}$ or parisite stacking sequences across the $c$ axis (Figure $11 \mathrm{~b}, \mathrm{c}$ ). Such transformations are associated with aspects suggestive of overprinting rather than growth at equilibrium. These include layer-wide jogs between $S$ and $B$ slabs in the $B_{2} S$ and parisite sequences, slab darkening indicating absence of Ln or Ca cations (Figure 11c), as well as irregular interfaces associated with lattice strain in the slabs (Figure 11d). 


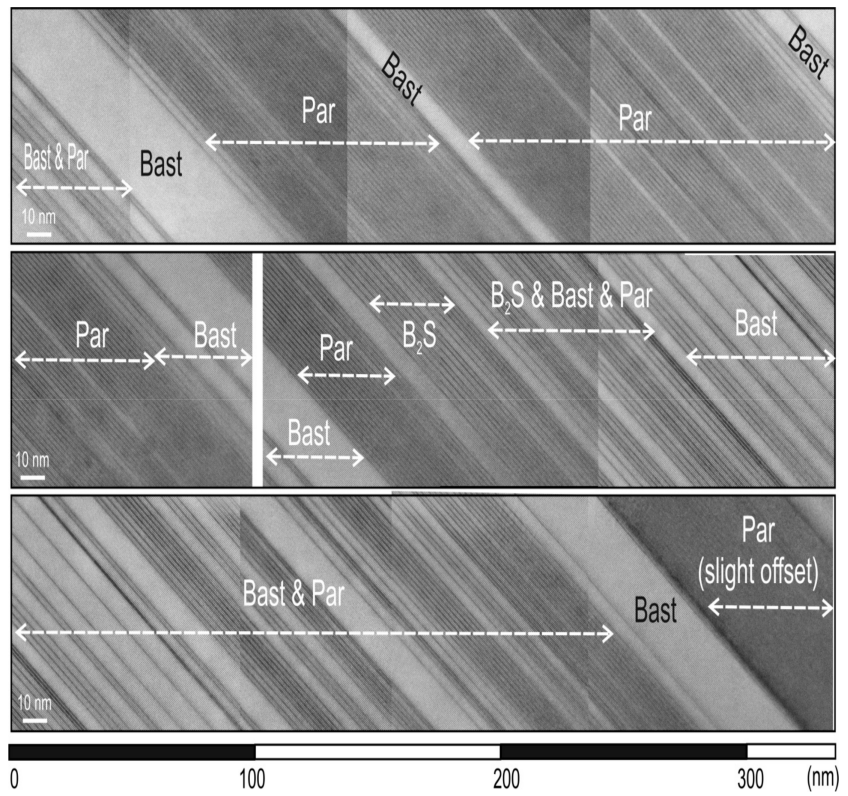

Figure 10. Short-range stacking disorder over a $\sim 1 \mu \mathrm{m}$-long profile across lamellar intergrowths from area 6 (marked on Figure 3f); specimen tilted down to [10 - 10] zone axis. The HAADF STEM imaging shows $100 \mathrm{~nm}$ periods of bastnäsite and parisite with gradational changes to intergrowths between 2and 3-species (as marked). Bast—bastnäsite; Par-parisite.

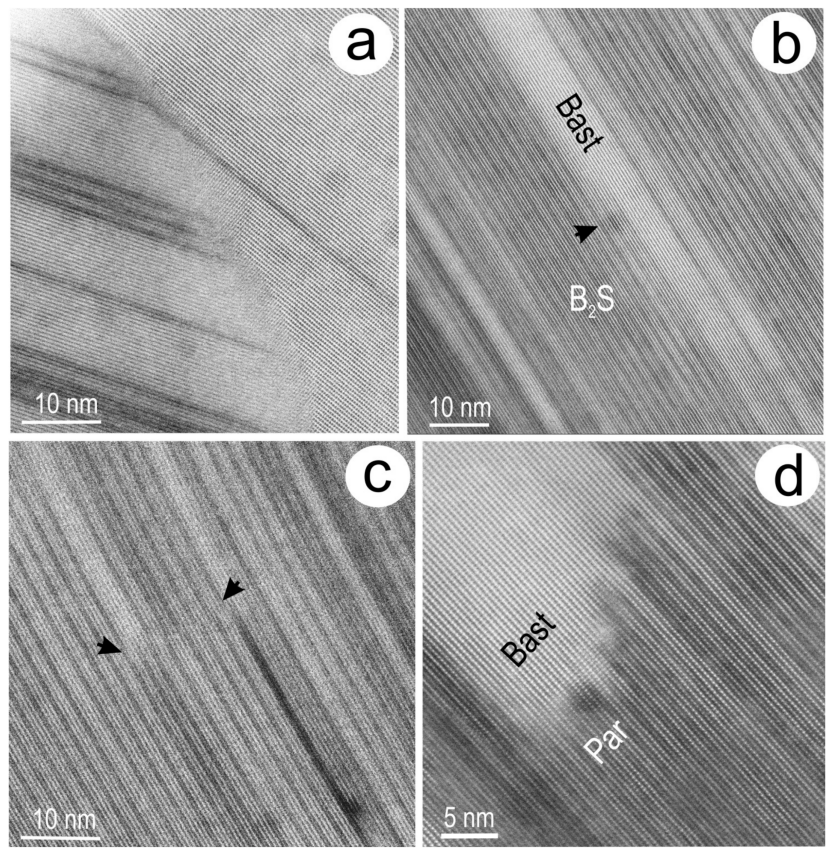

Figure 11. Details of grain boundaries (a) and changes in the slab stack perpendicular to the layer stacking direction (c-e) illustrating co-crystallisation and overprint, respectively. HAADF STEM images are taken down to [-1100] for $(\mathbf{a}, \mathbf{d})$ and to [10 - 10] for $(\mathbf{b}, \mathbf{c})$; (a) Stepwise, 1-2 atom-wide adjustment between two lamellae of bastnäsite with variable defects as slabs of parasite; $(\mathbf{b}, \mathbf{c})$ Apparent transformation of bastnäsite into $\mathrm{B}_{2} \mathrm{~S}$ or parisite stacking sequences across the $c$ axis shown as changes between $B$ and $S$ slabs on directions perpendicular to the $c$ axis; (d) Irregular interface between bastnäsite and parisite suggesting replacement between the two phases. Note the lattice strain in the slabs along this interface. Bast-bastnäsite; Par-parisite. 


\section{Discussion}

The present study provides further insights into: (i) the definition of species and crystal-structural modularity in mixed-layer REE-fluorocarbonate compounds in the bastnäsite-synchysite group; and (ii) the significance of short-range stacking disorder and coherent changes of stacks for genetic interpretations.

We report here a second occurrence of the $\mathrm{B}_{2} \mathrm{~S}$ phase found among sequences of parisite and bastnäsite within the studied lamellar intergrowths. The longest BBS sequence ( 19 A wide) contains up to $\sim 22$ repeats, or $11 \times \mathrm{B}_{2} \mathrm{~S}$ unit cells if we consider that $2 \times \mathrm{BBS}$ repeats represent a single unit cell with hexagonal symmetry. Indeed, both $\mathrm{B}_{2} \mathrm{~S}$ and associated parisite show hexagonal lattices, as documented from electron diffractions and HAADF STEM imaging from the two zone axes (Figure 4d-f, Figures $5 \mathrm{c}-\mathrm{e}$ and $8 \mathrm{~b}-\mathrm{d}$ ) obtained by tilting the specimen around the $c^{*}$ or $c$ axis, respectively, at the same location. The lattice vectors defining the reciprocal space with distances at $(\sim 2 \AA \times 3)$ and $(\sim 4.7 \AA \times 6)$ do not give orthogonal solutions for indexing the electron diffractions when using the monoclinic cell for parisite [17].

Parisite and $\mathrm{B}_{2} \mathrm{~S}$ species documented here are most likely $2 \mathrm{H}$ polytypes with $c=28 \AA\left(c=6 \times c^{\prime \prime \prime}\right)$ and $c=38 \AA\left(c=8 \times c^{\prime \prime \prime}\right)$, respectively. $2 H$ parisite is a new, short hexagonal polytype that can be added to the 14 polytypes (both hexagonal and rhombohedral) that have been reported so far (Table S4; $[16,21,22])$. The $2 \mathrm{H} \mathrm{B}_{2} \mathrm{~S}$ polytype is a species among the seven variants reported from the occurrence in China (Table S4; [19]).

Two polytypes of bastnäsite are identified (Figures $4 b, c$ and $5 b$ ): the $2 H$ polytype with $P-62 c$ space group [15,17], and a new species in which the presence of $000 l$ reflections with $l \neq 2 n$ indicates the absence of 2 -fold operators along $c$. This is possibly a $1 H$ polytype with $P-62 m$ as one of the compatible space groups.

The specific features of diffraction patterns for mixed-layer compounds can be interpreted using a model superstructure in which two layer/slab types, although with different structures, fit epitaxially along the planar interfaces between the slabs [3]. Based on previous and present data, the correlation between satellite reflections and the number of layers along the stacking direction $\left(c^{*}\right)$ can be written empirically as: $\mathrm{N}_{\text {sat }}=[(\mathrm{m} \times 2)+(\mathrm{n} \times 4)]-1$ for all $\mathrm{B}_{\mathrm{m}} \mathrm{S}_{\mathrm{n}}$ compounds with $\mathrm{S} \neq 0$ (Table 1$)$. The number of satellites can vary; however, due to extinctions associated with symmetry elements in certain space groups, e.g., the number is half for phases within $P-62 c$ space group due to the reflection condition $000 l, l=2 n$.

Variation in satellite intensity can occur due to lattice-scale intergrowths as interpreted here, or from the complexity of blocks within a given polysome. For example, the stacking sequence in the hexagonal polytype representing the $\mathrm{B}_{10} \mathrm{~S}_{6}$ polysome can be written either as $(3 \times \mathrm{BBS}) \cdot(\mathrm{BS}) \cdot(\mathrm{BBS}) \cdot(\mathrm{BS})$, or the equivalent hierarchical sequence: $B_{7} S_{4} \cdot B_{3} S_{2}$ (Figure $1 b$ ). The number of satellite reflections is predictable from the layer stacking (Table 1) but not the variation in the intensity of satellite reflections displayed along $c^{*}[18]$. Its significance lies, however, within polysomatism in the group, requiring further studies with respect to modularity concepts akin to mixed-layer compounds. For example, a model of displacive modulation vectors have shown that the diffraction patterns, with two brightest reflections about the middle of $d_{1}{ }^{*}$, are described by monotonic decrease of two modulations with increase in $\mathrm{Bi}$ in mixed-layered compounds from the tetradymite group in the compositional range $\mathrm{Bi}_{2} \mathrm{Te}_{3}-\mathrm{Bi}_{8} \mathrm{Te}_{3}[31]$.

Overall, the lattice-scale intergrowths account for the compositional range between bastnäsite and parisite revealed by electron probe microanalysis (Figure 2d; Tables S1-S3). In detail, the compositional range, which is almost continuous between parisite and $B_{2} S$, is covered either by rhythmic intervals of parisite and bastnäsite, or by stacking sequences with gradational changes in the slab stacking between B, BBS and BS types as exemplified by the $\sim 1 \mu \mathrm{m}$ profile image shown as Figure 10. As shown in this study, HAADF STEM imaging is a well-suited tool for direct imaging of the stacking sequences as these are readily depicted by the arrays of heavier atoms ( $\mathrm{Ln}$ and $\mathrm{Ca}$ ). None of the polysome sequences defining the four species in the compositional range between the $B_{2} S$ phase and parisite $\left(B_{7} S_{4}, B_{10} S_{6}\right.$, 
$\mathrm{B}_{3} \mathrm{~S}_{2}$ and $\mathrm{B}_{8} \mathrm{~S}_{6}$; Table 1 , Figure $1 \mathrm{~b}$ ) were identified, although random blocks of variable $\mathrm{B}, \mathrm{BS}, \mathrm{BBS}$ or $\mathrm{S}$ slab widths are seen across any of the gradational intervals in the $\sim 1 \mu \mathrm{m}$ profile (Figure 10).

In contrast, the compositional interval between the $\mathrm{B}_{2} \mathrm{~S}$ phase and parisite is covered by long-range polysomes and their polytypes, as known from the reported occurrence in China [18,19,21,22]. Such differences between the two occurrences may indicate that the same compositional range can be expressed by epitaxial intergrowths between either short- or long-range stacking polysomes/polytypes. In the present study, short-range stacking disorder occurs across blocks tens to hundreds of $\mathrm{nm}$ in size, precluding ordering of long-range period phases. Whereas both types of sequences can be presumed to originate via primary growth mechanisms, the growth rates differ depending upon the state of disequilibrium or (close-to-) equilibrium, respectively, of the thermodynamic system. We suggest that such phenomena, typical of syntaxial intergrowths, may be mechanisms for $\mathrm{Ca}-\mathrm{CO}_{3}$ layer adjustment within hexagonal/rhombohedral lattices as opposed to the monoclinic shift interpreted from X-ray diffraction (XRD) studies of pure compounds [23,24].

In addition to the short-range stacking disorder, HAADF STEM imaging shows changes between different stacking sequences across grain boundaries, or along directions perpendicular to the stack ( $c$ axis; Figure 11). In the latter case, the interface between such changes is either straight or irregular (Figure 11c,d, respectively), inferring adjustment of the layers due to sharp chemical gradients. The irregular boundaries between bastnäsite and parisite, nonetheless preserving the coherence of atom arrays along the $c$ axis, can be attributed to atom-scale replacement reactions whereby $\mathrm{Ca}-\mathrm{CO}_{3}$ layers are converted into $\mathrm{LnF}-\mathrm{CO}_{3}$ layers or vice versa. This can be attributed to processes responsible for chemical changes without open spaces such as metasomatism, with mechanisms of atom exchange invoking either diffusion across chemical gradients, or fluids that can infiltrate at lattice-scale. Such a process, imaged here at the atomic scale, is part of a broader spectrum of replacement reactions that advance by sharp fronts of fluid-mineral reaction by coupling dissolution with reprecipitation rates (CDRR; [32,33]). The importance of CDDR-driven mechanisms of mineral replacement throughout the hydrothermal evolution at Olympic Dam has been emphasised previously for different minerals and /or mineral pairs, including feldspars [12,13], uraninite $\pm \mathrm{Cu}$-Fe-sulphides [34-36], and hematite [37].

\section{Implications and Outlook}

In contrast to the lattice-scale intergrowths discussed here, end-member bastnäsite and synchysite have been documented from hematite-sericite-altered breccias hosting the Olympic Dam orebody [11]. On the other hand, the intimate, lattice-scale, relationships between BSG minerals and hematite [12] are not unique to this occurrence, a prospect distal to the deposit, but are also observed within the orebody, in which hematite hosts inclusions of BSG species [37]. These will be documented and discussed in further detail elsewhere. They are important for understanding the link between Fe- and REE-metasomatism at Olympic Dam, and for IOCG deposits in general. The present occurrence clearly carries significance in defining the early stage of magmatic feldspar alteration in deposits belonging to the IOCG clan, whereby Ca can be inferred to be derived from albitization and REE, $\mathrm{F}$, and $\mathrm{CO}_{2}$ are introduced by hydrothermal fluids. The fact that such changes are mediated via CDRR (pseudomorphic replacement of feldspars) rather than open-fracture fluid circulation suggests that these elements are derived from the host granite rather than any other external source. The lattice-scale intergrowths documented here show that the compositional space between parisite and bastnäsite is accommodated by species within this interval without any synchysite present, supporting thermodynamic modelling of phase equilibria that indicate stepwise changes in composition between the two end-members in the group [4].

As shown here, HAADF STEM imaging is most appropriate for depiction of stacking sequences and their changes in mixed-layer compounds, particularly those in which heavy atoms (Ln) are essential components. This technique is however not readily applicable to visualisation of the lighter atoms; in this case, the internal geometry of the $\mathrm{CO}_{3}$ layers responsible for polytype identification. In follow-up studies, we will investigate if such atoms can be imaged by HAADF STEM at lower $\mathrm{kV}$. 
REE-fluorocarbonates are an exemplary group among other mixed-layer compounds which include shear structures, long-period antiphase boundary structures, polysynthetic twins, and in general periodic interface modulated structures [3]. Crystal structure modularity in such groups can be defined by different formalism concepts, as exemplified here by the polysomatic descriptions of BSG minerals [15-17,29]. Other examples of mixed-layer compounds that would benefit from atomic-scale HAADF STEM imaging of the stacking sequences include the NC-pyrrhotites, recently redefined by translation modulation interface ([38] and references therein), or the layer-module types which are considered to explain polysomatism in $\mathrm{Bi}$ - and $\mathrm{Bi}-\mathrm{Pb}$-chalcogenides of the tetradymite group and related aleksite series [31,39-41].

Supplementary Materials: The following are available online at www.mdpi.com/2075-163X/7/10/227/s1, Figure S1: BF TEM images showing Foil 2, Figure S2: BF low- and high-resolution TEM images showing aspects of the intergrowths in both foils, Table S1-S3: EPMA data, Table S4: Published data on polytypes of (A) parisite and (B) $\mathrm{B}_{2} \mathrm{~S}$.

Acknowledgments: This research was fully supported by BHP Olympic Dam. Adelaide Microscopy and the Australian Microscopy and Microanalysis Research Facility are gratefully acknowledged for access to instrumentation and the time for Titan Themis sessions. Cristiana L. Ciobanu acknowledges support from the "FOX" project (Trace elements in iron oxides: deportment, distribution, and application in ore genesis, geochronology, exploration, and mineral processing), sponsored by BHP Olympic Dam and the S.A. Mining and Petroleum Services Centre of Excellence. We thank two anonymous reviews for their insightful comments which help us improve our manuscript.

Author Contributions: Cristiana L. Ciobanu, Alkis Kontonikas-Charos, Ashley Slattery and Benjamin Wade performed all analytical work. Cristiana L. Ciobanu devised the project and guided all analysis and interpretation. Cristiana L. Ciobanu also wrote the paper, assisted by Nigel J. Cook, Alkis Kontonikas-Charos and Kathy Ehrig.

Conflicts of Interest: The authors declare no conflict of interest.

\section{References}

1. Ciobanu, C.L.; Cook, N.J.; Maunders, C.; Wade, B.P.; Ehrig, K. Focused Ion Beam and Advanced Electron Microscopy for Minerals: Insights and Outlook from Bismuth Sulphosalts. Minerals 2016, 6, 112. [CrossRef]

2. Utsunomiya, S.; Ewing, R.C. Application of high-angle annular dark field scanning transmission electron microscopy, scanning transmission electron microscopy-energy dispersive X-ray spectrometry, and the energy-filtered transmission electron microscopy to the characterization of nanoparticles in the environment. Environ. Sci. Technol. 2003, 37, 786-791. [PubMed]

3. Van Tendeloo, G.; Bals, S.; van Aert, S.; Verbeek, J.; van Dyck, D. Advanced electron microscopy for advanced materials. Adv. Mater. 2012, 24, 5655-5675. [CrossRef] [PubMed]

4. Gysi, A.P.; Williams-Jones, A.E. The Thermodynamic Properties of Bastnäsite-(Ce) and Parisite-(Ce). Chem. Geol. 2015, 392, 87-101. [CrossRef]

5. Guastoni, A.; Nestola, F.; Giaretta, A. Mineral Chemistry and Alteration of Rare Earth Element (REE) Carbonates from Alkaline Pegmatites of Mount Malosa, Malawi. Am. Mineral. 2009, 94, 1216-1222. [CrossRef]

6. Miyawaki, R.; Yokoyama, K.; Husdal, T.A. Bastnäsite-(Nd), a new Nd-dominant member of the bastnäsite group from the Stetind pegmatite, Tysfjord, Nordland, Norway. Eur. J. Mineral. 2013, 25, 187-191. [CrossRef]

7. Augé, T.; Bailly, L.; Wille, G. An Unusual Occurrence of Synchysite-(Ce) in Amygdules from the Esterel Volcanic Rocks, France: Implications for Rare-Earth Element Mobility. Can. Mineral. 2014, 52, 1-19. [CrossRef]

8. Smith, M.P.; Henderson, P.; Campbell, L.S. Fractionation of the REE during Hydrothermal Processes: Constraints from the Bayan Obo Fe-REE-Nb Deposit, Inner Mongolia, China. Geochim. Cosmochim. Acta 2000, 64, 3141-3160. [CrossRef]

9. Groves, D.I.; Vielreicher, N.M. The Phalabowra (Palabora) carbonatite-hosted magnetite-copper sulfide deposit, South Africa: An end-member of the iron-oxide copper-gold-rare earth element deposit group? Miner. Deposita 2001, 36, 189-194. [CrossRef]

10. Ehrig, K.; McPhie, J.; Kamenetsky, V.S. Geology and mineralogical zonation of the Olympic Dam iron oxide $\mathrm{Cu}-\mathrm{U}-\mathrm{Au}-\mathrm{Ag}$ deposit, South Australia. In Geology and Genesis of Major Copper Deposits and Districts of the World, a Tribute to Richard Sillitoe, Hedenquist, J.W., Harris, M., Camus, F., Eds. SEG Spec. Publ. 2012, 16, 237-268. 
11. Schmandt, D.S.; Cook, N.J.; Ciobanu, C.L.; Ehrig, K.; Wade, B.P.; Gilbert, S.; Kamenetsky, V.S. Rare earth element fluorocarbonate minerals from the Olympic Dam Cu-U-Au-Ag deposit, South Australia. Minerals 2017, 7, 202. [CrossRef]

12. Kontonikas-Charos, A.; Ciobanu, C.L.; Cook, N.J.; Ehrig, K.; Krneta, S.; Kamenetsky, V.S. Feldspar Evolution in the Roxby Downs Granite, Host to Fe-Oxide Cu-Au-(U) Mineralisation at Olympic Dam, South Australia. Ore Geol. Rev. 2017, 80, 838-859. [CrossRef]

13. Kontonikas-Charos, A.; Ciobanu, C.L.; Cook, N.J.; Ehrig, K.; Ismail, R.; Krneta, S.; Basak, A. Feldspar mineralogy and rare earth element (re)mobilization in iron-oxide copper gold systems from South Australia: A nanoscale study. Mineral. Mag. 2018, in press. [CrossRef]

14. Williams-Jones, A.E.; Wood, S.A. A preliminary petrogenetic grid for REE fluorocarbonates and associated minerals. Geochim. Cosmochim. Acta 1992, 56, 725-738. [CrossRef]

15. Donnay, G.; Donnay, J.D.H. The crystallography of bastnaesite, parisite, roentgenite and synchysite. Am. Mineral. 1953, 38, 932-963.

16. Van Landuyt, J.; Amelinckx, S. Multiple Beam Direct Lattice Imaging of New Mixed-Layer Compounds of the Bastnaesite-Synchisite Series. Am. Mineral. 1975, 60, 351-358.

17. Ni, Y.; Hughes, J.M.; Mariano, A.N. The Atomic Arrangement of Bastnäsite-(Ce), $\mathrm{Ce}\left(\mathrm{CO}_{3}\right) \mathrm{F}$, and Structural Elements of Synchysite-(Ce), Rontgenite-(Ce), and Parisite-(Ce). Am. Mineral. 1993, 78, 415-418.

18. Wu, X.L.; Meng, D.W.; Pan, Z.L.; Yang, G.M.; Li, D.X. Transmission Electron Microscopic Study of New, Regular, Mixed-Layer Structures in Calcium-Rare-Earth Fluorocarbonate Minerals. Mineral. Mag. 1998, 62, 55-64.

19. Meng, D.; Wua, X.; Han, Y.; Meng, X. Polytypism and microstructures of the mixed-layer member $B_{2} S$, $\mathrm{CaCe}_{3}\left(\mathrm{CO}_{3}\right)_{4} \mathrm{~F}_{3}$ in the bastnaesite-(Ce)-synchysite-(Ce) series. Earth Planet. Sci. Lett. 2002, 203, 817-828. [CrossRef]

20. Van Tendeloo, G.; van Dyck, D.; Kuypers, S.; Amelinckx, S. Electron Diffraction Effects in Mixed Layer Compounds. I. Theoretical Considerations. Phys. Statuds Solidi 1987, 101, 339-354.

21. Meng, D.; Wu, X.; Mou, T.; Li, D. Microstructural investigation of new polytypes of parisite-(Ce) by high-resolution transmission electron microscopy. Can. Mineral. 2001, 39, 1713-1724. [CrossRef]

22. Meng, D.; Wu, X.; Mou, T.; Li, D. Determination of six new polytypes in parisite-(Ce) by means of high-resolution electron microscopy. Mineral. Mag. 2001, 65, 797-806.

23. Ni, Y.; Post, J.E.; Hughes, J.M. The Crystal Structure of Parisite-(Ce), $\mathrm{Ce}_{2} \mathrm{CaF}_{2}\left(\mathrm{CO}_{3}\right)_{3}$. Am. Mineral. 2000, 85, 251-258. [CrossRef]

24. Wang, L.; Ni, Y.; Hughes, J.M.; Bayliss, P.; Drexler, J.W. The atomic arrangement of synchysite-(Ce), $\mathrm{CeCaF}\left(\mathrm{CO}_{3}\right)_{2}$. Can. Mineral. 1994, 32, 865-871.

25. Ungemach, H. Sur la syntaxie et la polytypie. Z. Krist.-Cryst. Mater. 1935, 91, 1-22. [CrossRef]

26. Yang, G.M.; Tao, K.; Zhang, P. The symmetry transformations of modules in baestnasite-vaterite polysomatic series. N. Jahrb. Mineral. Monatsh. 1998, 1-12.

27. Meyer, H.J. Struktur und Fehlordnung des Vaterits. Z. Krist.-Cryst. Mater. 1969, 128, 183-212. [CrossRef]

28. Ferraris, G.; Makovicky, E.; Merlino, S. Crystallography of Modular Materials; Oxford University Press: Oxford, UK, 2008.

29. Makovicky, E. Vaterite: Interpretation in terms of OD theory and its next of kin. Am. Mineral. 2016, 101, 1636-1641. [CrossRef]

30. Ciobanu, C.L.; Cook, N.J.; Utsunomiya, S.; Pring, A.; Green, L. Focussed ion beam-transmission electron microscopy applications in ore mineralogy: Bridging micron- and nanoscale observations. Ore Geol. Rev. 2011, 42, 6-31. [CrossRef]

31. Ciobanu, C.L.; Pring, A.; Cook, N.J.; Self, P.; Jefferson, D.; Dima, G.; Melnikov, V. Chemical-structural modularity in the tetradymite group: A HRTEM study. Am. Mineral. 2009, 94, 517-534. [CrossRef]

32. Putnis, A. Mineral replacement reactions: From macroscopic observations to microscopic mechanisms. Mineral. Mag. 2002, 66, 689-708. [CrossRef]

33. Ruiz-Agudo, E.; Putnis, C.V.; Putnis, A. Coupled dissolution and precipitation at mineral-fluid interfaces. Chem. Geol. 2014, 383, 132-146. [CrossRef]

34. Macmillan, E.; Cook, N.J.; Ehrig, K.; Ciobanu, C.L.; Pring, A. Uraninite from the Olympic Dam IOCG-U-Ag deposit: Linking textural and compositional variation to temporal evolution. Am. Mineral. 2016, 101, 1295-1320. [CrossRef] 
35. Macmillan, E.; Ciobanu, C.L.; Ehrig, K.; Cook, N.J.; Pring, A. Chemical zoning and lattice distortion: Uraninite from Olympic Dam, South Australia. Am. Mineral. 2016, 101, 2351-2354. [CrossRef]

36. Macmillan, E.; Ciobanu, C.L.; Ehrig, K.; Cook, N.J.; Pring, A. Replacement of uraninite by bornite via coupled dissolution-reprecipitation: Evidence from texture and microstructure. Can. Mineral. 2016, 54, 1369-1383. [CrossRef]

37. Verdugo-Ihl, M.R.; Ciobanu, C.L.; Cook, N.J.; Ehrig, K.J.; Courtney-Davies, L.; Gilbert, S. Textures and U-W-Sn-Mo signatures in hematite from the Olympic Dam Cu-U-Au-Ag deposit, South Australia: Defining the archetype for IOCG deposits. Ore Geol. Rev. 2017, in press. [CrossRef]

38. Harries, D.; Pollok, K.; Langenhorst, D. Translation interface modulation in NC-pyrrhotites: Direct imaging by TEM and a model toward understanding partially disordered structural states. Am. Mineral. 2011, 96, 716-731. [CrossRef]

39. Cook, N.J.; Ciobanu, C.L.; Wagner, T.; Stanley, C.J. Minerals of the system Bi-Te-Se-S related to the tetradymite archetype: Review of classification and compositional variation. Can. Mineral. 2007, 45, 665-708. [CrossRef]

40. Cook, N.J.; Ciobanu, C.L.; Stanley, C.J.; Paar, W.; Sundblad, K. Compositional data for Bi-Pb tellurosulfides. Can. Mineral. 2007, 45, 417-435. [CrossRef]

41. Moëlo, Y.; Makovicky, E.; Mozgova, N.N.; Jambor, J.L.; Cook, N.; Pring, A.; Paar, W.; Nickel, E.H.; Graeser, S.; Karup-Møller, S.; et al. Sulfosalt systematics: A review. Report of the sulfosalt sub-committee of the IMA Commission on Ore Mineralogy. Eur. J. Mineral. 2008, 20, 7-62.

(C) 2017 by the authors. Licensee MDPI, Basel, Switzerland. This article is an open access article distributed under the terms and conditions of the Creative Commons Attribution (CC BY) license (http://creativecommons.org/licenses/by/4.0/). 